\title{
ORIGIN AND EVOLUTION OF THE SUB-ANTARCTIC ISLANDS: THE FOUNDATION
}

\author{
by Patrick G. Quilty
}

(with 23 text-figures and two tables)

\begin{abstract}
Quilty, P.G. 2007 (23:xi): Origin and evolution of the sub-Antarctic islands: the foundation. Papers and Proceedings of the Royal Society of Tasmania 141(1): 35-58. https://doi.org/10.26749/rstpp.141.1.35 ISSN 0080-4703. School of Earth Sciences, University of Tasmania, Private Bag 79, Hobart, Tasmania 7001, Australia. Email: P.Quilty@utas.edu.au
\end{abstract}

Sub-Antarctic islands have a diversity of origins in detail but most are volcanic and very young suggesting that they are short-lived and that the distribution would have been very different a few million years ago. They contrast with the common tourist brochure concept of oceanic islands. As the Antarctic Plate is virtually static, the islands seldom show signs of association with long-lived linear island chains and most thus stand alone. Longer-lived islands are either on submarine plateaux or are continental remnants of the dispersion of Gondwana. The islands are classified in relation to raised sea-floor, transform fault, triple junction, subduction zone, submarine plateau, submerged continent or continental. Many are difficult of access and poorly known geologically. Their geological history controls their many other roles such as sites as observatories, or for study of colonisation, evolution and speciation rates.

Key Words: Sub-Antarctic islands, geological evolution, Macquarie Island, Balleny Islands, Scott Island, Campbell Island, Antipodes Island, Auckland Islands, Enderby Island, Peter I Island, Islas Diego Ramirez, South Georgia, South Sandwich Islands, Bouvetøya, Gough Island, Marion Island, Prince Edward Island, îles Crozet, Amsterdam Island, St Paul Island, Kerguelen Plateau, Îles Kerguelen, Heard Island, McDonald Island.

\section{INTRODUCTION}

The sub-Antarctic for this paper is taken as the area of the sea-floor and land between the base of the Antarctic continental slope and a poorly-defined latitude, normally somewhere about $50^{\circ} \mathrm{S}$ but also extending well north of that to include Gough Island at $40^{\circ} 21^{\prime} \mathrm{S}$ and Amsterdam and Saint Paul islands at $35-38^{\circ}$. It includes the islands of interest to the Scientific Committee on Antarctic Research (SCAR) (Bonner \& Lewis Smith 1985, Dingwall 1995). One criterion for inclusion is the absence of a permanent resident human population. It thus includes the greater part of what is now termed the Antarctic Tectonic Plate (fig. 1), a few pieces of the African, Australia-Indian and Pacific tectonic plates, and a series of tectonic micro-plates north of the Antarctic Peninsula. The sea-floor of the area formed as part of the break-up of the super-continent of Gondwana, beginning some 160 million years ago - mid-Jurassic in geological terms (fig. 2) and representing events in the last $3.5 \%$ of Earth history.

Knowledge of the origin and evolution of the islands is critical to any consideration of the time constraints on other features of the islands such as landform evolution or biological diversity.

The total area of the sub-Antarctic islands is $<14000 \mathrm{~km}^{2}$ (table 1) but if the largest island groups (South Georgia and

TABLE 1

Sub-Antarctic islands considered in this review, showing location and area

\begin{tabular}{llcl}
\hline Island & \multicolumn{1}{c}{ Location } & Area $\left(\mathrm{km}^{2}\right)$ & \multicolumn{1}{c}{ Age (Ma) } \\
\hline Amsterdam \& St Paul & $35^{\circ} 52^{\prime}-38^{\circ} 43^{\prime}, 77^{\circ} 30^{\prime} \mathrm{E}$ & 58 & $<0.5$ \\
Antipodes Island & $49^{\circ} 41^{\prime} \mathrm{S}, 178^{\circ} 46^{\prime} \mathrm{E}$ & 20 & $<0.5$ \\
Auckland Island & $50^{\circ} 50^{\prime} \mathrm{S}, 166^{\circ} 05^{\prime} \mathrm{E}$ & 620 & Continental \\
Balleny Islands & $66^{\circ} 55^{\prime} \mathrm{S}, 163^{\circ} 20^{\prime} \mathrm{E}$ & 400 & $<10$ \\
Bouvetøya & $54^{\circ} 26^{\prime} \mathrm{S}, 3^{\circ} 25^{\prime} \mathrm{E}$ & 50 & $<1$ \\
Campbell Island & $52^{\circ} 33^{\prime} \mathrm{S}, 169^{\circ} 09^{\prime} \mathrm{E}$ & 120 & Continental \\
Illes Crozet (Possession) & $46^{\circ} 25^{\prime} \mathrm{S}, 51^{\circ} 38^{\prime} \mathrm{E}$ & 400 & $9-0$ \\
Diego Ramirez & $56^{\circ} 30^{\prime} \mathrm{S}, 68^{\circ} 42^{\prime} \mathrm{W}$ & c. 2 & Continental \\
Gough Island & $40^{\circ} 21^{\prime} \mathrm{S}, 9^{\circ} 55^{\prime} \mathrm{W}$ & 65 & 1 \\
Heard \& McDonald Is. & $53^{\circ} 06^{\prime} \mathrm{S}, 73^{\circ} 31^{\prime} \mathrm{E}$ (Big Ben) & 380 & $40,9,1-0:$ Active \\
Iles Kerguelen & $49^{\circ} 21^{\prime} \mathrm{S}, 70^{\circ} 12^{\prime} \mathrm{E}$ & 6500 & $39-25 ; 23-17$ \\
Macquarie Island & $54^{\circ} 30^{\prime} \mathrm{S}, 158^{\circ} 57^{\prime} \mathrm{E}$ & 200 & 9 \\
Marion \& Pr. Edward Is. & $46^{\circ} 52^{\prime} \mathrm{S}, 37^{\circ} 51^{\prime} \mathrm{E}$ (Marion) & 350 & $0.45-$ Recent \\
Peter I Island & $68^{\circ} 50^{\prime} \mathrm{S}, 90^{\circ} 35^{\prime} \mathrm{W}$ & c. 200 & $0.3-0.1$ \\
Scott Island & $67^{\circ} 24^{\prime} \mathrm{S}, 179^{\circ} 55^{\prime} \mathrm{W}$ & $<1$ & "very young" \\
South Georgia & $54^{\circ} 17^{\prime} \mathrm{S}, 36^{\circ} 30^{\prime} \mathrm{W}$ & 3755 & Continental \\
South Sandwich Is. & $56^{\circ} 20^{\prime}-59^{\circ} 20^{\prime} \mathrm{S}, 26^{\circ}-28^{\circ} \mathrm{W}$ & 618 & 3,1 : Active \\
\hline
\end{tabular}




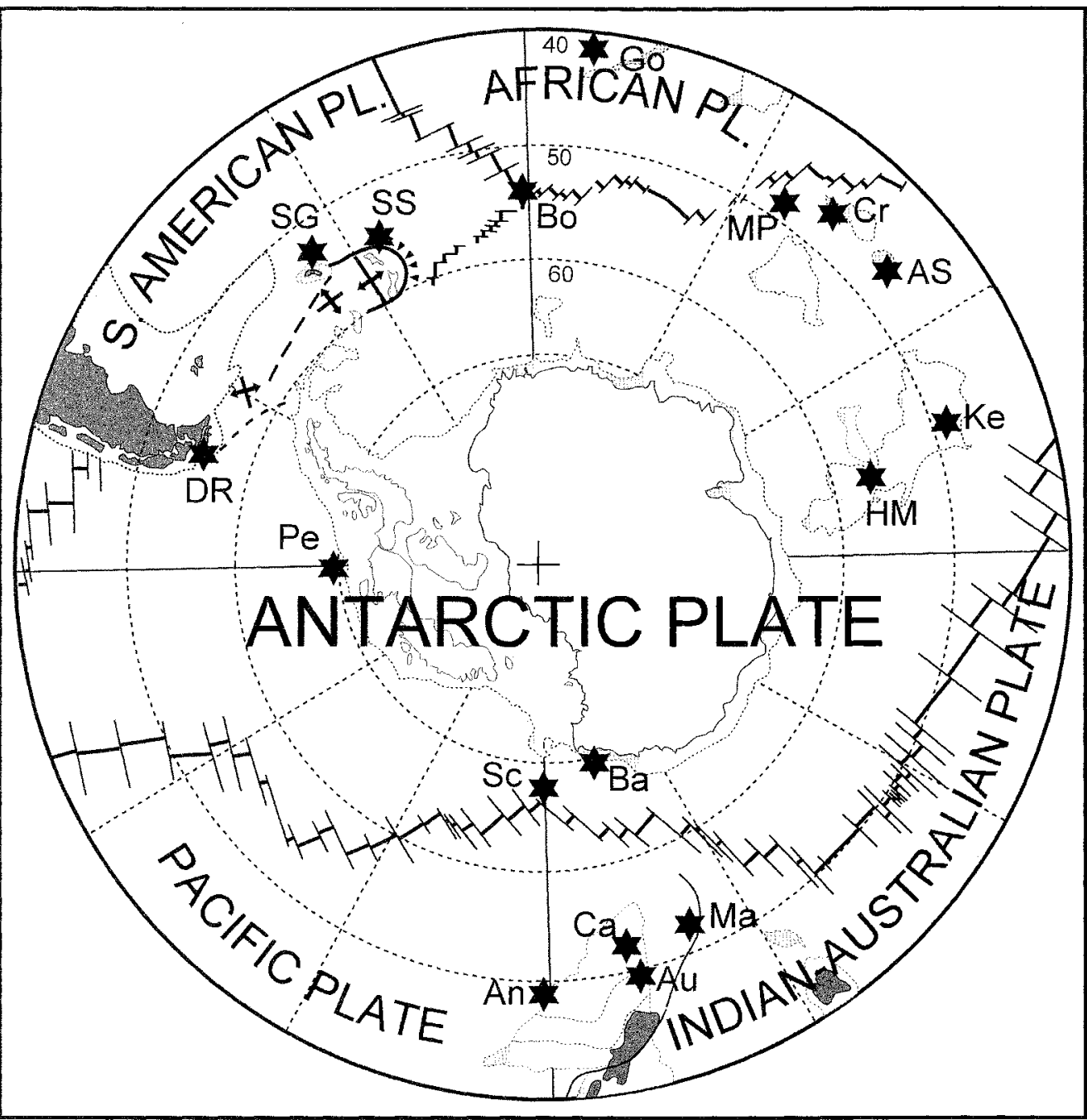

FIG. 1 -Islands of the sub-Antarctic in their plate tectonic context. AS = Amsterdam \& St Paul Is.: An = Antipodes Is.; $A u=$ Auckland Is, $B a=$ Balleny Is.; Bo = Bouvet Is.; $C a=$ Campbell Is.; $C r=$ Crozet Is.; $D R=$ Diego Ramirez Is.; Go = Gough Is.; HM = Heard or McDonald Is.; Ke = Kerguelen Is.; $M a=$ Macquarie Is.; $M P=$ Marion of Prince Edward Is.; Pe = Peter I Is.; Sc $=$ Scott Is.; SG = South Georgia; $S S=$ South Sandwich Is.

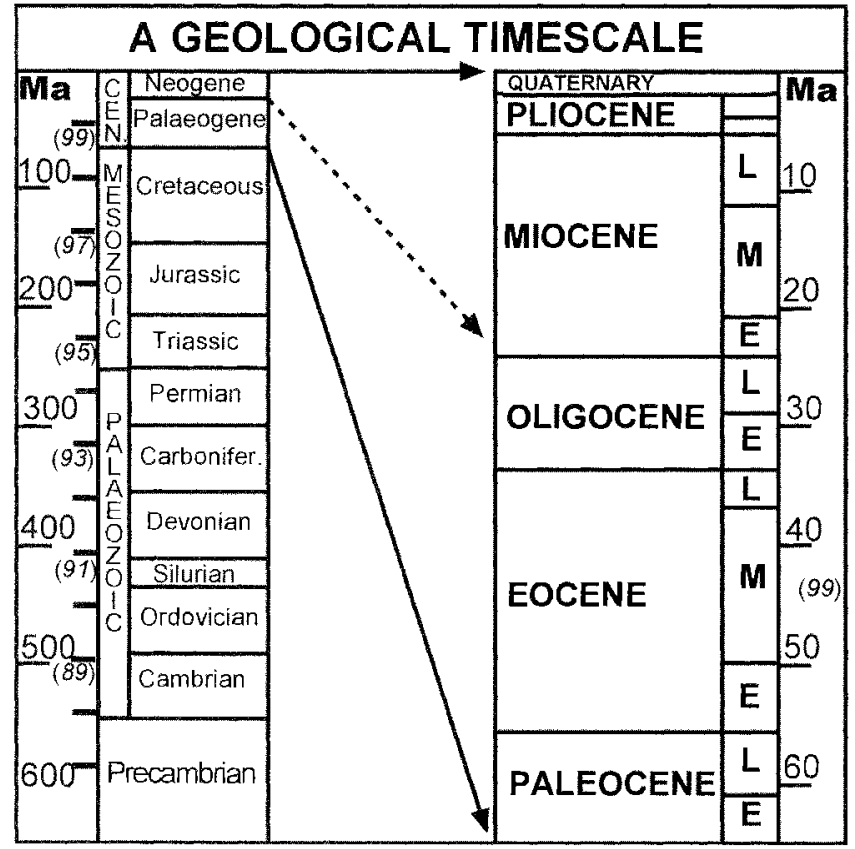

FIG. 2 - Geological timescale employed. This covers the last 600 million years. Numbers in italics and parentheses are percentages of Earth history that has passed before this time.

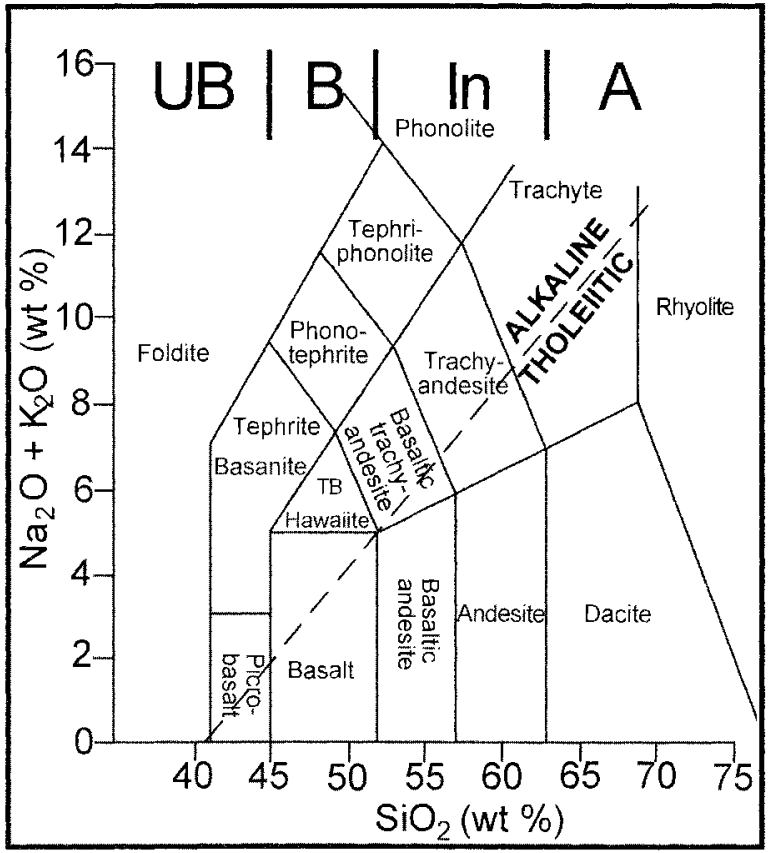

FIG. 3 - Classification of volcanic rocks including most of the types referred to in this paper. $T B=$ trachybasalt: $U B=$ ultrabasic (or ultramafic): $B=$ basic (or mafic): In = intermediate: $A=$ acid. 
Îles Kerguelen) are excluded, the figure is slightly over 3000 $\mathrm{km}^{2}$. For all their being small specks in a vast area, they are valuable as sites for marine-based organisms to inhabit, breed and moult, and for humans to build observatories. Their history provides controls on rates of evolution and colonisation. In recent years, many international programs (such as the Deep Sea Drilling Project and Ocean Drilling Program) have been concerned with the evolution of the oceans and ocean floors which cover $71 \%$ of the earth's surface. The sub-Antarctic islands, largely volcanic (using that term broadly), are relatively accessible sites allowing access to a variety of volcanic rocks and assist in gaining an understanding of the sources of oceanic lavas and conditions at the sites of generation of these lavas in the earth's mantle.

The islands are often on structures such as Macquarie Ridge and Kerguelen Plateau that have very great significance oceanographically by controlling the direction of deep water flow and in many instances, the shallow water flow, especially as that varies during periods of low sea level — for example at glacial maxima. Some of these major structures have varied in depth for tectonic reasons over time and such variation, coupled with changing continental positions, has had an influence in the longer term evolution of global climate.

Concepts of islands are commonly influenced by brochures and images of the Indo-Pacific where clean white carbonate reefs and atolls abound and where Darwin developed the concept of atolls forming as rings around the top of progressively submerging volcanoes. Such island chains are attributed to migration of tectonic plates over a "melting anomaly" or "hot-spot" within the mantle. Islands in the Pacific Ocean commonly, almost normally, are in the form of linear chains such as the Hawaiian island chain, with an active volcano at one end of a sequence of islands that are getting older, lower and more highly eroded with time and distance from the modern volcano. Individual islands form during a single episode of volcanism over perhaps a million years, when activity ceases for a while as the oceanic crust moves over the hot-spot - the source of the lava from various depths in the earth's mantle. After a few million years, eruption begins again but by this time the chain has moved and a new volcano and island forms. Eventually the islands subside below sea level to become a seamount, or, if flat-topped, a guyot. In most oceans of the world, hot-spot sites are used to measure movement of the tectonic plate over such hot-spots but the Antarctic plate is different in that it is essentially stationary and thus provides a good site for studying aspects of the hot-spots themselves. Hot-spot linear island chains are not to be expected. The distribution and features of sub-Antarctic islands lead to questions of the too-ready acceptance of the "hot-spot/plume" concept as an explanation for all phenomena.

The Earth has two surface expressions. Continental crust floats above the earth's mantle and thus has the potential to retain its entire 4.5 billion-year-history, in contrast with oceanic crust which is regularly subduced into the mantle and thus modern oceanic floors have a maximum age of about 180 million years. As continents move apart, new sea-floor is generated at a mid-ocean ridge (MOR) such as that between Australia and Antarctica, or roughly centrally in the Atlantic Ocean. The elevation of the ridge is normally at about $2.8 \mathrm{~km}$ water depth and this is the depth at which basaltic sea-floor generally forms. Segments of ridge crest are offset by transform faults which have a characteristic geometry. Ridge crests are the site of smaller, shallow earthquakes in contrast to subduction zones where large, deep, catastrophic earthquakes are more prevalent. Ridge crests, are the site of the phenomena associated with "black smokers" and their unusual life forms commonly attracting widespread interest because of their ability to live under extreme physico-chemical conditions.

This paper follows a route (fig. 1) from Tasmania, through Macquarie Island, Balleny islands, via Scott Island to the New Zealand sub-Antarctic islands on Campbell Plateau, then east to the Antarctic Peninsula/South American region and South Atlantic Ocean, before entering the Indian Ocean and terminating at the Heard and McDonald islands.

The aim is to summarise at a consistent technical level, the geological evolution of the islands as a basis on which other sciences can build, for example by showing how old the islands are and the influence age has on colonisation and subsequent rates of evolution. It also attempts to classify the islands according to origin and draw out the difference between sub-Antarctic islands and the popular conception of more temperate and tropical islands. While most research on the sub-Antarctic has concentrated on the volcanic rocks, several areas have substantial sedimentary sequences of a variety of ages and sedimentary environments, including Quaternary peat or glacial deposits. The comments in this paper refer mainly to the geology of the islands themselves and not so much to the geology of the surrounding seafloor, other than to a general summary of the evolution of that sea-floor.

The reference list is not comprehensive and lists only enough papers to provide an adequate summary of the geology of the individual islands. Brief summaries of the volcanic characteristics of many are provided by a variety of authors in LeMasurier \& Thomson (1990) who consider only those islands that are specifically volcanic and include many that are not considered here: conversely, this paper includes several not covered by LeMasurier \& Thomson (1990).

The following terminology is used in this paper. $\mathrm{Ma}$ is used to denote the age in millions of years before present; ka refers to thousands of years; m.y. is used to indicate an age difference, whenever that may have been. Figure 2 is a geological timescale employing that used by Geoscience Australia, modified in the younger section by reference to Berggren et al. (1995).

Most of the rocks encountered on the sub-Antarctic islands are volcanic in origin. One classification of such rocks, based on $\mathrm{SiO}_{2}$ and $\mathrm{Na}_{2} \mathrm{O}$ and $\mathrm{K}_{2} \mathrm{O}$ content, is shown in figure 3 .

The break-up of Gondwana has had a critical influence on the region. When Gondwana began to disintegrate $(160 \mathrm{Ma})$, Antarctica had been situated roughly over the South Pole for approximately 150 million years since moving south from the Northern Hemisphere. The region over the South Pole was all continental crust with distant ocean surrounding it. None of the sea-floor evident around Antarctica today existed. The entire super-continent at 160 Ma was populated with plants and dependent animals with much in common throughout the various modern fragments of Gondwana. Convenient summaries of the evolution of Gondwana are contained in Cande \& Stock (2004 - Australia-New Zealand-Antarctica), Larter et al. (2002 - Pacific sector), Cunningham et al. (2002 Pacific sector), Royer \& Sandwell (1989 - Indian Ocean), and Royer \& Coffin (1992 - Indian Ocean). 

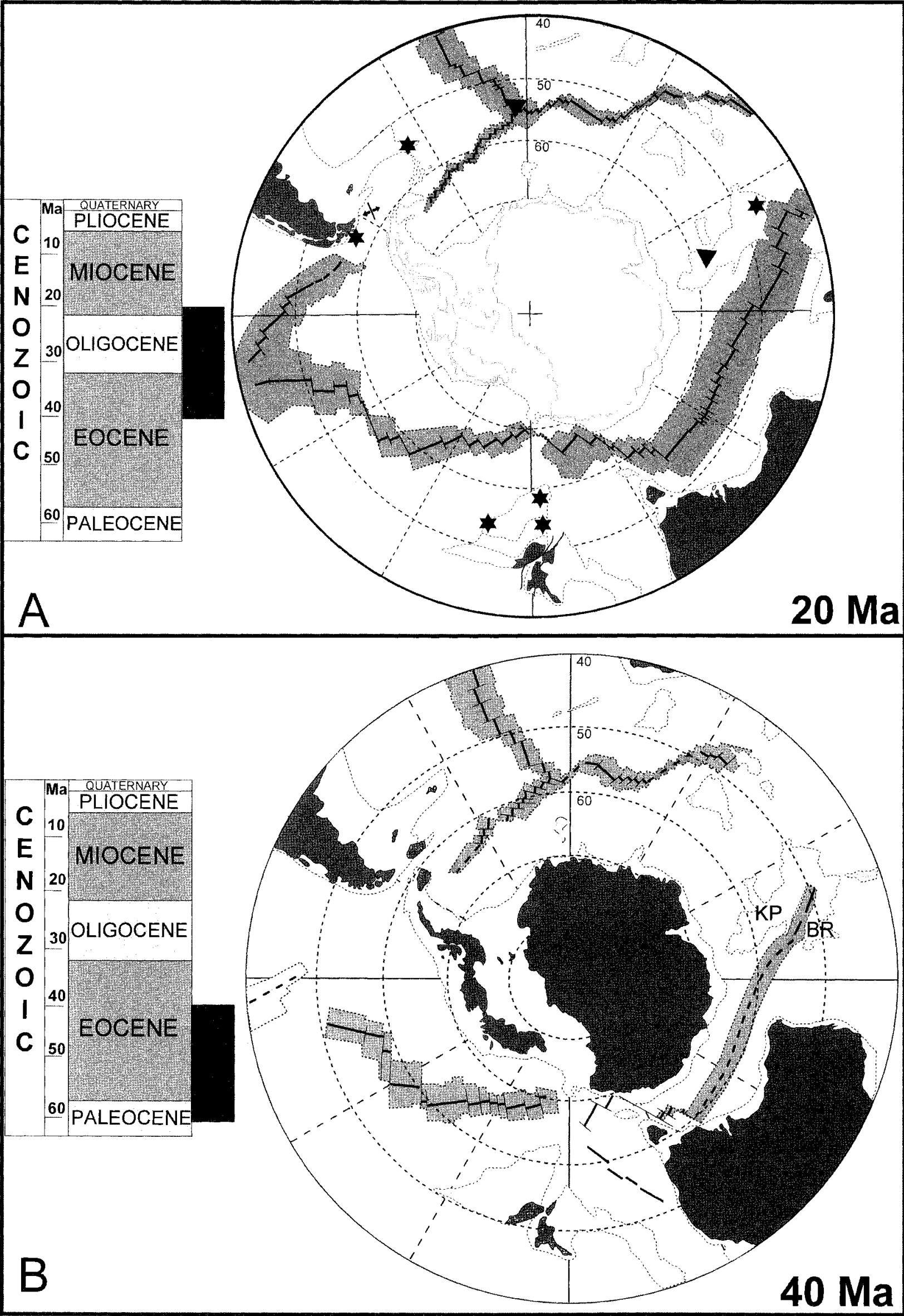

FIG. 4 - Antarctic Tectonic Plate boundaries at (A) $20 \mathrm{Ma}$ and (B) $40 \mathrm{Ma}$. The area that grew at mid-ocean ridge in the previous $20 \mathrm{~m} . y$. is shaded. Stars represent islands that existed at the time (see also fig. 1); triangles, islands that existed in part. Antarctica shaded in $4 B$ to indicate that it was vegetated in contrast to $4 A$ when it is white to indicate a glaciated state. 
Figure 4 illustrates the evolution of the Antarctic Plate between 40 and $20 \mathrm{Ma}$ and each of the two maps shows the amount of sea-floor formed (and thus dispersion of the continents) in the previous 20 m.y.

At about 55 m.y., Australia accelerated its movement north to its current rate of about $6 \mathrm{~cm} /$ year. This was to have momentous consequences. By $34 \mathrm{Ma}$ (Exon et al. 2004), Australia had moved north far enough that deep-ocean circulation could occur between Australia and Antarctica. With the development of deep ocean circumpolar circulation, Antarctica was completely isolated (as were Australia and South America) and assumed its current glaciated state with the consequent extinction of almost all terrestrial fauna and flora. It developed an icesheet and $99.3 \%$ of Earth history had passed by this time. The Southern Ocean linked the

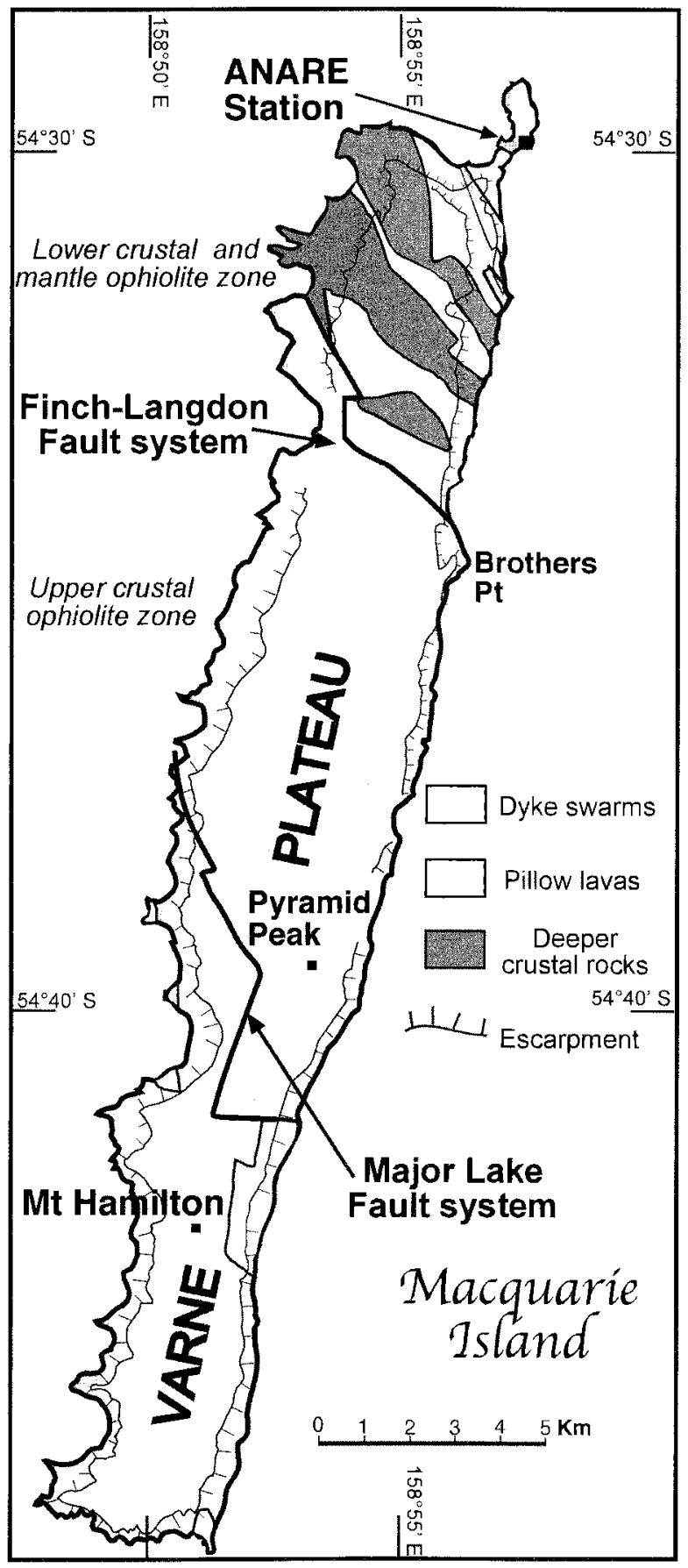

FIG. 5- Macquarie Island
Indian, Pacific and Atlantic oceans and washed Antarctica's shores. The oceanic crust of the Southern Ocean continued expanding by growth at mid-ocean ridges, but hardly any of the sub-Antarctic islands had come in to being by 20-30 Ma.

\section{MACQUARIE ISLAND}

Macquarie Island (Banks \& Smith 1988, Selkirk et al. 1990) is on the Pacific Plate, very close to and east of the boundary between the Australian/Indian and Pacific Plates (fig. 1). Macquarie Ridge, first identified by Bellingshausen in 1820 , marks that boundary which is tectonically very active at present and large earthquakes are common. Macquarie Ridge links Macquarie Island and New Zealand where it continues as the Alpine Fault. The island (fig. 5) is marked by a surface plateau, the main part now identified as Varne Plateau, falling from over $400 \mathrm{~m}$ at its southern end, to about $250 \mathrm{~m}$ at the north. This probably represents old sea floor and some small hills may be remnants of submarine volcanoes. The plateau is surrounded by steep scree slopes on which landslips are common. The rugged western side of the island is sepatated from the ocean by a narrow raised platform; this feature is less well developed on the eastern side but where present, provides a convenient site for penguin and seal colonies. The surface of the island has been disrupted by faulting and small scarps are obvious and common.

The rocks that make up Macquarie Island (Varne et al. 2000) formed at a mid-ocean ridge at $9 \mathrm{Ma}$ (Late Miocene; Quilty et al. in press). Dating rocks has been difficult but recent discovery of enigmatic bolboforms has provided a precise fossil-based date on the assumption that extrusion of pillow lavas and deposition of sediments was coeval. The island is cut by two complex transform faults - the Finch-Langdon and Major Lake Fault systems (Wertz et al. 2003). It consists of a variety of igneous and sedimentary rocks typical of a cross section through the oceanic crust (Varne et al. 1969). North of the Finch-Langdon Fault System, the rocks are from deeper in the crust and include a greater variety of intrusive rocks (gabbro, peridotite, dolerite dyke swarms and extrusive volcanic basalts, in addition to sediments including deep-sea nanno/foram ooze and volcanic sediment). In contrast, those of the southern $80 \%$ of the island are more like the near-surface rocks of the ocean floor with a higher concentration of pillow lavas and sediments. The complex formed initially at a slow spreading mid-ocean ridge/transform fault complex, probably at an ocean depth of some $2.8 \mathrm{~km}$. With time, it sank into deeper water but probably not below the carbonate compensation depth (CCD) as carbonate sediments commonly show no evidence of dissolution.

Interaction between the tectonic plates led to uplift of the island and that process continues. Macquarie Island contains many old beach levels attesting to past coastlines. It is unclear what the current rate of uplift of the island is and it may vary from place to place. Adamson et al. (1996) reviewed various possibilities and suggested that Macquarie Island emerged above sea level approximately 600 000-700 000 years ago. Since the first emergence, the amount of the island above sea level has varied greatly, reflecting both tectonic instability and changes in global sea level consequent on climate changes.

The unique geological features of the island as a wellpreserved cross-section through oceanic crust were the basis for its inscription, in 1997, on the World Heritage List. 


\section{BALLENY ISLANDS AND SCOTT ISLAND}

The five major Balleny islands (fig. 6) form a linear series related to the Tasman Fracture Zone, a zone of closely spaced transform faults that passes from Antarctica, via the Balleny islands, to the southern and western margins of Tasmania. Because of their steep coasts, access to the islands is difficult and much work remains to be done. The islands are the subaerial expression of a series of submarine ridges including the Balleny Seamounts to the northwest, the ANARE Seamounts to the southeast, and farther southeast and parallel is another seamount chain - the Admiralty Seamounts. The entire complex lies very close to the location of a transform fault

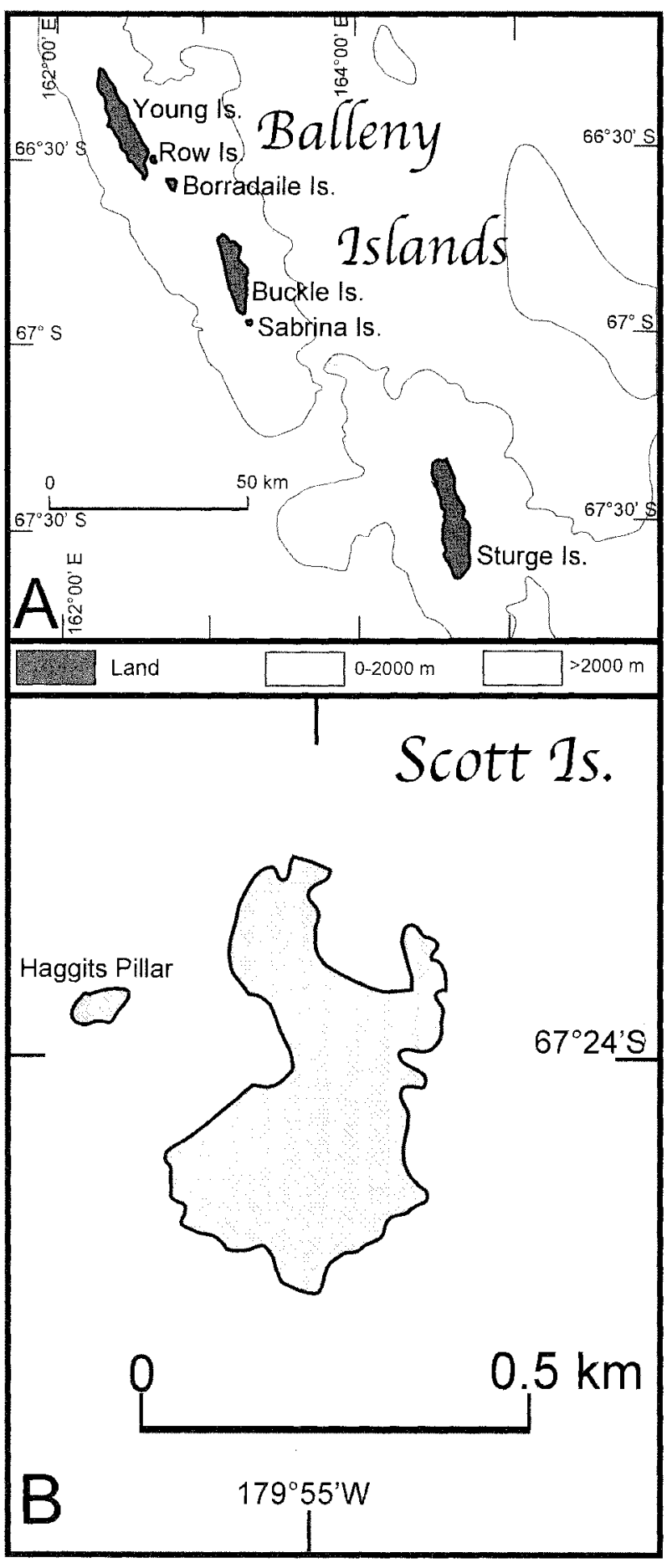

FIG. 6- (A) Balleny islands and (B) Scott Island.
(Lanyon 1994) but the relationship with that fault is not clear. The Balleny island chain with its submarine extensions is oriented north-northwest-south-southeast parallel to the local transform faults.

The islands formed by subaerial volcanic activity and the rocks are olivine trachybasalt with minor olivineaugite basalt and fit in the basanite-hawaiite field (fig. 3). They are in the form of agglomerates, tuffs and lava flows with obvious stratification, sporadically red-coloured due to oxidation at the time of eruption. The Balleny island chain has been linked to the evolution of New Zealand but a fracture zone/transform fault link with southern or western Tasmania is more accurate. These islands have been attributed to hot-spot activity (Green 1992, Lanyon et al. 1993, Lanyon 1994) but it has also been suggested that they result from intermittent activity along a transform fault that is under some oblique tension and thus could be "leaky" (Kyle \& Cole 1974), and in this regard may be similar in origin to Gough Island. The islands are close to the site of a major earthquake in March 1998, the largest magnitude earthquake recorded in that year to that time.

The age of the volcanism is not well documented but analysis of nearby sea-floor magnetic lineations suggests that they are all less that $10 \mathrm{Ma}$. Radiometric dating of samples from the southern island - Sturge Island - indicates a Quaternary age of less than $2 \mathrm{Ma}$ (Embleton 1984, Jenkins et al. 1992). Reports of many early expeditions stated that the islands were in eruption but there is no evidence that this is true and no modern infrared satellite imagery has detected any evidence of heat sources; the confusion probably stems from the unusual cloud formations that appear normally to cover the islands.

Tiny Scott Island seems to be a relatively normal volcanic island but it is not well studied. Its age is not known but is believed to be very young. It is the small projection above sea level at the northern end of a small, north-south oriented plateau (Scott Plateau - $145 \times 30 \mathrm{~km}$ ) which in turn sits on Eocene (about $40 \mathrm{Ma}$ ) sea-floor. Part of the Plateau is northwest-southeast oriented and is parallel to the Scott Seamount chain about $65 \mathrm{~km}$ to the southwest. This chain in turn is parallel to the Balleny Seamount chain and the histories of the two island groups are connected. Wright \& Kyle (1990b) summarised what was known at the time and Lanyon (1994) examined further samples collected by dredging from adjacent to Scott Island.

The rocks of the island and surrounds are described as phonolites and phonotephrites, characterised by high $\mathrm{Na}_{2} \mathrm{O}+\mathrm{K}_{2} \mathrm{O}$ (normally $12-13 \%$ in the phonolites and $9 \%$ in the phonotephrites) and thus are very similar to the Balleny Island rocks and have a similar origin.

\section{CAMPBELL PLATEAU ISLANDS}

South of New Zealand is an extension of thinned continental crust about $25 \mathrm{~km}$ thick in contrast to the usual $40-50 \mathrm{~km}$ and thus it lies below sea level. The area is the Campbell Plateau and an eastern extension - the Bounty Platform and is host to several islands or island groups - Campbell, Auckland and Antipodes islands - all lying north of the Antarctic Polar Frontal Zone. The islands contrast markedly with most sub-Antarctic islands geologically and historically. The basement of Campbell Plateau (Beggs et al. 1990) includes mica-rich granite with ages in the range of 92-115 Ma, similar to those which make up the Snares islands some 
$450 \mathrm{~km}$ due north of Auckland islands and also on Campbell Plateau. The granite intruded into older metasedimentary rocks (micaceous quartzite) similar to that known from Antarctica, New Zealand and the South Tasman Rise and thus is similar in setting and age to others well known from the former Gondwana.

Antipodes Island is somewhat unusual among this group in being entirely volcanic in its exposed geology. The other island groups - Campbell and Auckland - have a basement of continental rocks with a longer geological history, the continental crust acting as foundation for major shield volcanoes - similar to those of the eastern coastal region of South Island, New Zealand, i.e., near Christchurch and Dunedin - with low angle slopes, circular outline and a gentle form of eruption of low viscosity basaltic lava. The shield volcanoes at Campbell and Auckland islands were about the same size, around $25 \mathrm{~km}$ in diameter.

\section{Antipodes Island}

Although Antipodes Island (fig. 7) sits on the thinned continental crust of Campbell Plateau, the basement does not outcrop and what is preserved is the product of volcanic activity during the Pliocene and Quaternary (1-5 Ma) (Peat 2003) but Gamble \& Adams (1990a) suggest that the ages are generally younger, less than $1 \mathrm{Ma}$, probably $<0.5 \mathrm{Ma}$.

Antipodes Island is much smaller than either Campbell or Auckland islands and has two peaks - mts Galloway and Waterhouse - marking the position of the central volcanic cone and many smaller remnants. The highest point is $366 \mathrm{~m}$ but most of the island is an undulating plateau with cliffed margins to $150 \mathrm{~m}$ which show that much of the island consists of columnar basalt, the result of gentle eruption of low viscosity lava. The main lavas are low silica porphyritic lavas (basanite) with phenocrysts of olivine

To the northeast of the main island are two smaller islands (Bollons and Archway) which between them mark the eroded remains of a small volcano.

Antipodes Island shows no signs of having been affected by glaciation but has suffered considerable alluvial erosion to generate deep gullies. Like other Campbell Plateau islands, Antipodes Island has a layer of peat to $5 \mathrm{~m}$ thick.

\section{Campbell Island}

Campbell Island (fig. 8) consists of the remnants of one shield volcano but its western side has been eroded away leaving only the eastern part. The centre of the volcano is thought to have been at about Dent Island. Older sedimentary rocks are exposed around Northwest Bay, and the entrance to Perseverance Harbour.

The sediments around the margins of the southwestern part of the island (Northwest Bay, Penguin Bay, Rocky Bay and Tucker Cove in Perseverance Harbour) include a section of Cretaceous-Palaeogene rocks (Hollis et al. 1997). There are two formations - Garden Cove and Tucker Cove. The former is $30-100 \mathrm{~m}$ thick and consists of detrital conglomerate, sandstone and mudstone deposited in an initially non-marine environment which became marginally marine with time. This formation contains a few fossil groups, especially spores, pollen and dinoflagellates in addition to a few foraminifera and radiolarians. It is possible that the unit includes an almost complete section across the Cretaceous/

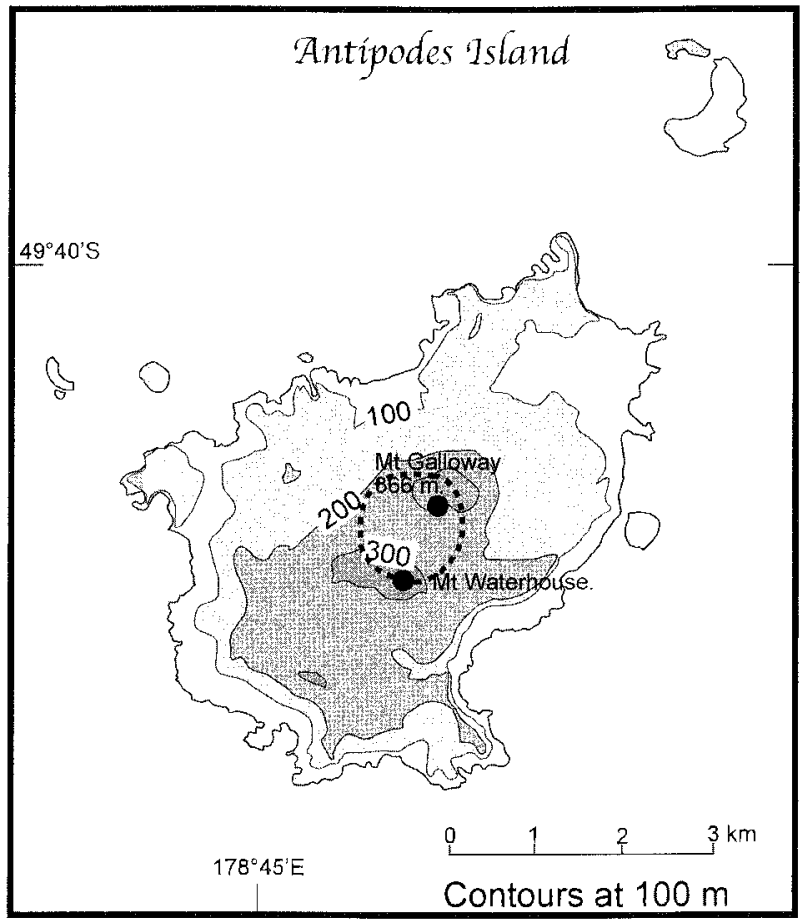

FIG. 7 - Antipodes Island

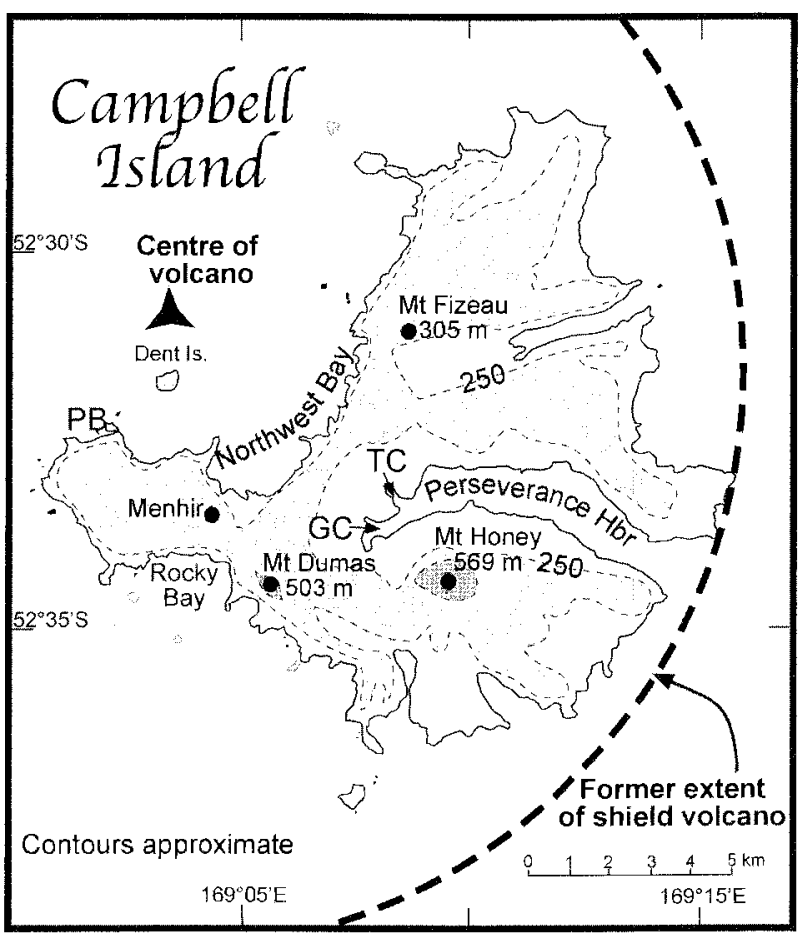

FIG. 8-Campbell Island. GC= Garden Cove; $P B=$ Penguin Bay; TC = Tucker Cove.

Tertiary boundary, the time when an asteroid impact led to extinction of dinosaurs and various other groups. This would be a very rare occurrence of such a section in shallow-water sediments. It is the most southerly outcrop of Cretaceous sediments in the South Pacific region (Hollis et al. 1997).

The Tucker Cove Formation is $100-200 \mathrm{~m}$ thick and consists of micritic limestone with some sand, glauconitic and nodular chert. It contains a diverse array of microfossils 
of Early Eocene to Oligocene age and includes within it a Middle Eocene angular unconformity representing a short time interval. It is possible that a complete Eocene-Oligocene section exists on the island but has not been located. After deposition of the sediments, gabbro was intruded at $16 \mathrm{Ma}$ (Middle Miocene) at Menhir (Morris \& Gamble 1990).

The sediments (and gabbro) have acted as the basement on which the main volcano was built. The volcanic accumulation consists of lava flows and pyroclastics and the wall of Perseverance Harbour provides a good view of the low-angle volcanic sediments and lava Hows. Volcanic activity is extinct and took place about 11-6 Ma, Mid to Late Miocene in geological terms. The volcanic rocks are quite diverse and include porphyritic hawaiites with phenocrysts of olivine and plagioclase. Minor trachyte and rhyolite flows also occur (Morris \& Gamble 1990).

Glacial landforms are not very obvious on Campbell Island but U-shaped valleys have been interpreted and the silled entrance to Perseverance Harbour may be either glacial till or composed of debris transported by longshore currents. There is some debate about the extent of glacial evidence but McGlone (2002) recorded till and possible lateral moraine at $90 \mathrm{~m}$ a.s.l., and possible kame terraces, terminal moraine and erratic blocks, all suggesting considerable ice cover at the Last Glacial Maximum (18 ka). The island has suffered extensive marine erosion on the western side and this has removed much of the original volcano.

Following cessation of glaciation, vegetation became re-established at about $15 \mathrm{ka}$ and similar changes to those noted on the Auckland islands are recorded at about 10 ka when tussock-grassland took over from macrophyllous forbs/herbfield. Another coeval change is noted at $7 \mathrm{ka}$ when scrub vegetation developed. As with other islands on Campbell Plateau, the vegetation history is now preserved in a widespread layer of peat $1-4 \mathrm{~m}$ thick.

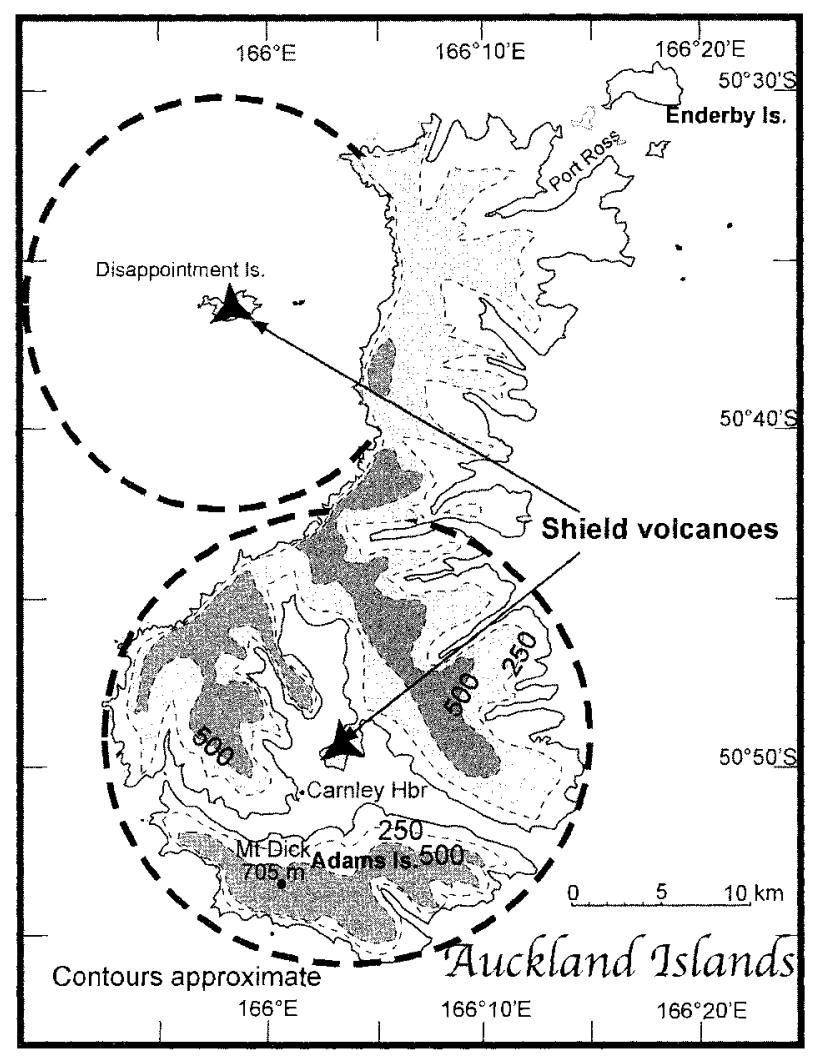

FIG. $9-$ Auckland islands

\section{Auckland islands}

The Auckland islands (fig. 9) consist of the major Auckland Island but also smaller Enderby Island at the northeast and very small Disappointment Island to the northwest. The islands have a history similar to that of Campbell Island but generally earlier, and consist of remnants of two shield volcanoes sitting on continental basement which, in Carnley Harbour, includes granite and a sequence of Cenozoic sedimentary rocks (Ritchie \& Turnbull 1990). The older sedimentary unit - latest Oligocene-Early Miocene Camp Cove Conglomerate 501-25 m thick - was deposited as a debris flow in a fluviatile environment and consists of matrixsupported clasts, mainly granitic. This is overlain by shallow marine Musgrave Formation about $15 \mathrm{~m}$ thick which has a diversity of rock types - quartz sandstone from a quartz/ feldspar source, limestone and a significant fossil fauna of bivalves, gastropods, brachiopods, echinoderms, bryozoans and foraminifera. This is Middle Miocene in age.

The Auckland Island complex (Gamble \& Adams 1990b) is the remnant of two shield volcanoes built on the older continental foundation. The southern of the two volcanoes is quite well-preserved, centred on Musgrave Peninsula in Carnley Harbour and its topographic outline is clear. The northwestern volcano was centred at Disappointment Island and is severely excavated on its western flank (similar to the situation at Campbell Island) and only the eastern part is preserved. Volcanism appears to have begun in the latest Oligocene (about $23.8 \mathrm{Ma}$ ) with younger volcanics and dyke intrusions continuing until the Middle Miocene (16.5 Ma).

Auckland Island was essentially ice-covered during the Last Glacial Maximum, and possibly several other times during the Late Cenozoic, and the eastern side of the northern volcano has suffered greatly but particularly at the Last Glacial Maximum some $18 \mathrm{ka}$. This has generated a series of marked deeply-incised fjords carved by glaciers flowing to the east. U-shaped valleys, hanging valleys, cirques at $250-300 \mathrm{~m}$ and moraine-dammed lakes are relics of this phase. As at Campbell Island, marine erosion resulting from heavy seas from this direction, has affected the western side of the complex more than the east which has been relatively protected and thus retains the best evidence of its glacial past.

Following the Last Glacial Maximum, vegetation recolonised the region from about $15 \mathrm{ka}$ and later vegetation changes occurred at $10-12 \mathrm{ka}, 7.5 \mathrm{ka}$ and $4 \mathrm{ka}$ when various vegetation types advanced as climate ameliorated. That at $10-12 \mathrm{ka}$ is most marked as tussock-grassland became established before the advent of small shrubs at about 4 ka (McGlone 2002). The remains of the vegetation and its record are preserved in an extensive peat layer $1-4 \mathrm{~m}$ thick in many places.

Enderby Island has a record of two phases of glacial deposition within the most recent glacial phase. It is very unusual in the region in having a white sand beach and dune system on its southern side, suggesting that the sand was derived from older continental rocks and brought to its current site ahead of sea level rise at the termination of the Last Glacial Maximum. 


\section{Peter I Island}

Peter I Island (fig. 10) was named by Bellingshausen in 1821, but he could not land because of its forbidding cliffs and ice cover. It covers some $154 \mathrm{~km}^{2}$ and is slightly elongate north-south with a roughly straight western coast and slightly embayed eastern coast. It is similar to the Balleny islands, in sitting on a transform fault where basalt lava has found an easy way to the surface, but differs from them in that it is a simple transform arrangement and a single island; there is no chain. It appears to have been a major shield volcano about $64 \mathrm{~km}$ in diameter that has now sunk considerably from its original elevation (Rowley 1990). The island is poorly known because of its remoteness.

The entire structure, of which the island is the exposed part, comprises about $2900 \mathrm{~km}^{3}$ of a large volcano on the ocean floor about $4000 \mathrm{~m}$ deep and the island rises to $1640 \mathrm{~m}$ above sea level with a small crater at its apex, approximately $100 \mathrm{~m}$ in diameter. The formation of this cone probably began 10-20 Ma (possibly the source of earlier age estimates of $12.5 \mathrm{Ma}$ come from samples taken at sea; Bastien \& Craddock 1976) on oceanic crust that is about $60 \mathrm{Ma}$. Ages of lavas from the island range from 100-330 $\mathrm{Ka}$. There is divided opinion about the origin of the island; is it a hot-spot or "leaky" transform source of lava? The rocks are very different from those of Jones Mountains, the closest similar rocks on the mainland of Antarctica. Hart et al. (1995) regarded Peter I Island as formed from hotspot lavas from a mantle source but the rocks differ from normal hot-spot lavas in having a high ${ }^{207 / 204} \mathrm{~Pb}$ signal. The transform model arises from the island's proximity to the Tharp Transform Fault (Prestvik et al. 1990).

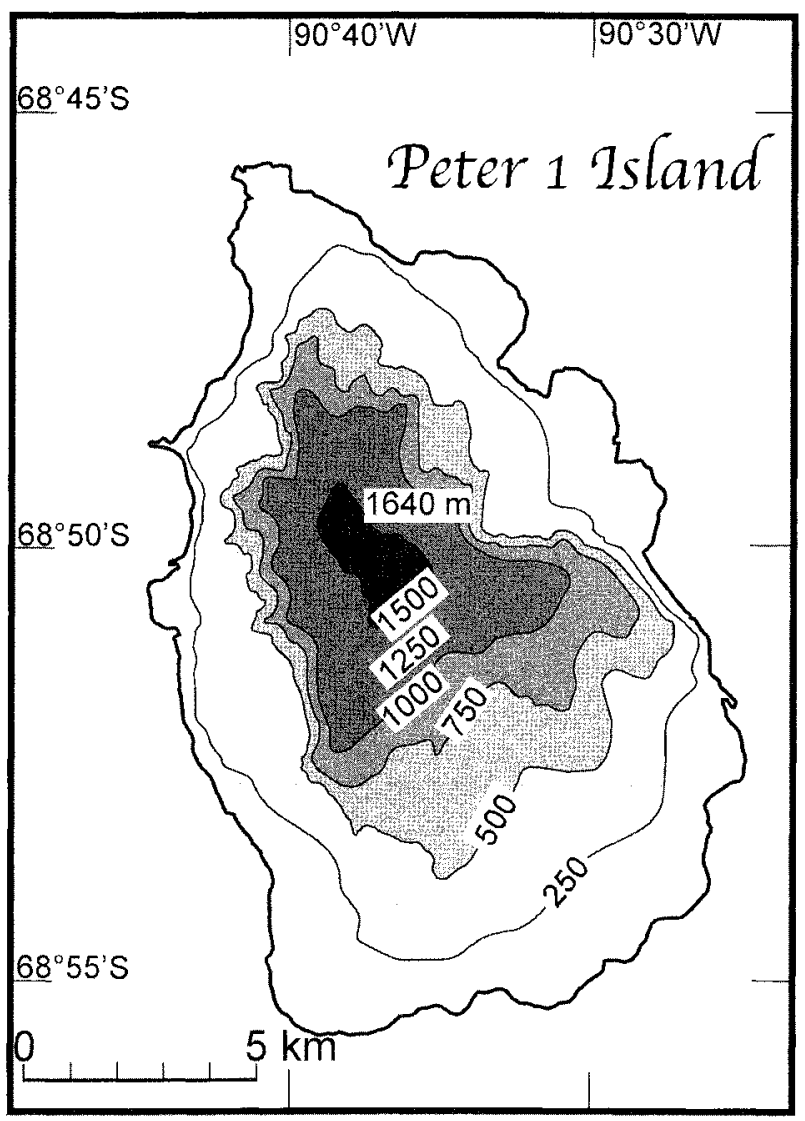

FIG. 10 - Peter I Island
The rocks consist of basalt and trachyandesite which has then been intruded by dykes and small plugs of basalt. The rocks incorporate a variety of xenoliths of gabbro and peridotite with a few of quartz rich continental crustal material. They vary from vesicular to massive and take the form of pahoehoe (ropey) lava attesting to subaerial eruption; pillow lavas, which would indicate submarine eruption, are absent.

\section{ISLANDS WITH HISTORY RELATED TO THAT OF SOUTH AMERICA AND THE ANTARCTIC PENINSULA}

The region between the southern tip of South America and the Antarctic Peninsula (fig. 11) is one of the geologically most complex areas on the earth's surface. The area includes islands such as South Georgia which is mainly continental, Shag Rocks which are continental, the South Sandwich Islands which are subduction-related, and Diego Ramirez Islands which are formed as a result of collision between the Pacific Ocean sea-floor and the continent of South America.

The structure and age of the sea-floor of the Scotia Sea west of the South Sandwich Islands has a multiphase history over a relatively short geological interval. Immediately west of the volcanic arc of the South Sandwich Islands lies a roughly north-south oriented spreading centre where the small Sandwich Plate (Cunningham et al. 1998) has been growing over the last $8 \mathrm{Ma}$. To the west of the new sea-floor thus formed, is older sea-floor of the Scotia Plate, due to an older episode of spreading (30-10 Ma) when South America and the northern Antarctic Peninsula separated in such a way that South America moved relatively northwest, north of a spreading ridge that was oriented northeast-southwest and subduction (now stopped) occurred under the northern margin of the Antarctic Peninsula. This plate is bounded at the west by the northwest-southeast oriented Shackleton Fracture Zone.

The Scotia Sea is bounded north and south by major transcurrent faults, the North and South Scotia Ridges with an east-west orientation. Both fault systems are marked by sinistral movement (north side relatively to the west) as South America moved west relative to the Antarctic Peninsula. Between the faults marked by the ridges, the Scotia Plate has evolved. The area involved is some $1800 \mathrm{x}$ $660 \mathrm{~km}$, oriented east-west.

\section{Islas Diego Ramirez}

The Diego Ramirez Islands (fig. 12A, B) consist of a few islands to $2 \mathrm{~km}$ long and many smaller rocky islets. Like so many of the sub-Antarctic islands, they have a northwestsoutheast orientation but this is due to their proximity to the subduction zone along the Chilean margin rather than to an association with a transform fault radiating from Antarctica. They lie on the Scotia Plate south of the North Scotia Ridge and east of the Shackleton Fracture Zone.

The islands are complex geologically. In contrast with many sub-Antarctic islands, they have a long and multiphase history (Wilson et al. 1991). They are part of a series of slabs of Pacific Ocean sea-floor that have accreted to the margin of southern Chile during a poorly-dated (perhaps late Palaeozoic-early Mesozoic) episode of subduction. The accretionary complex is made more complex by the presence 


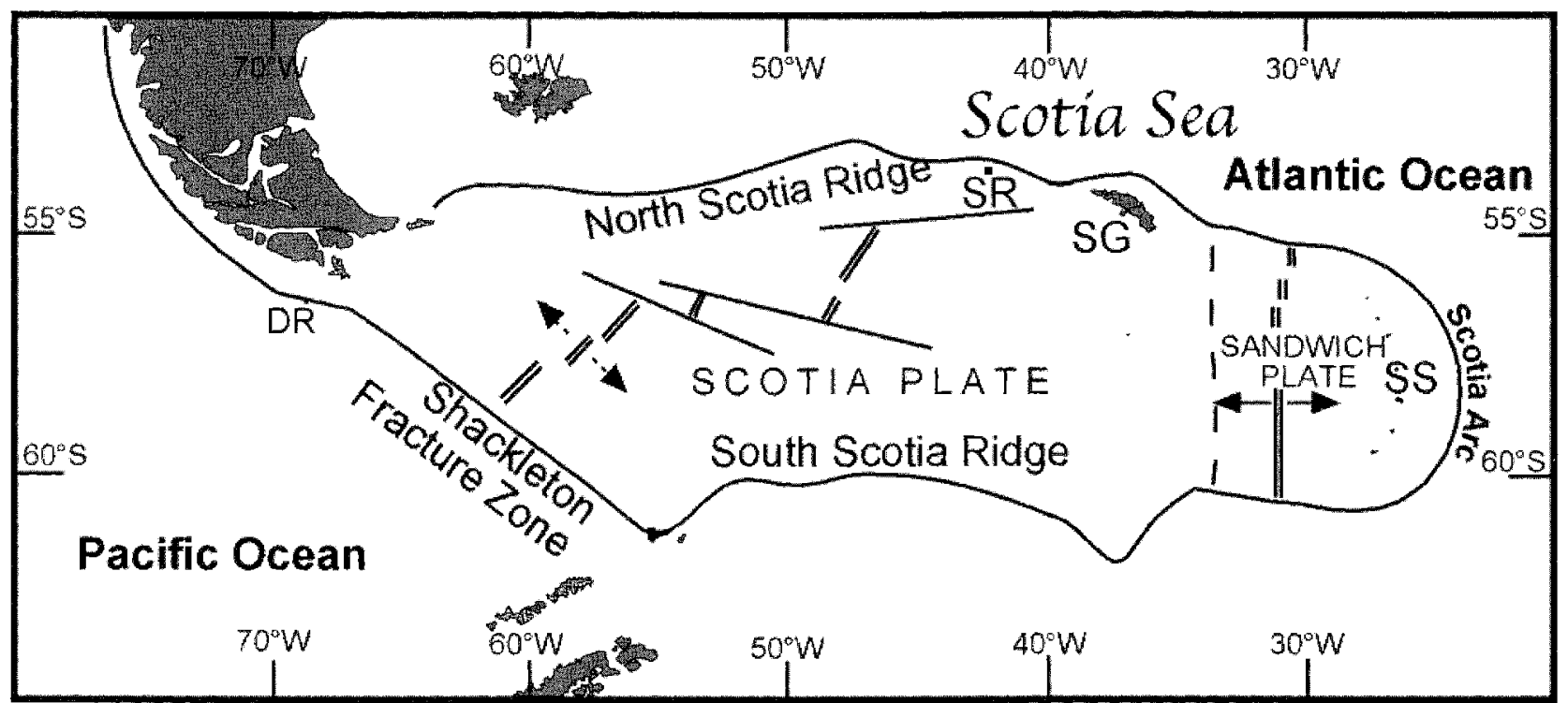

FIG. 11 - Tectonic sketch map of the Scotia Sea region. DR = Diego Ramirez Islands; SG = South Georgia; SR = Shag Rocks. Mid-ocean spreading centres shown by double parallel lines; those of the South Sandwich Plate are currently active.

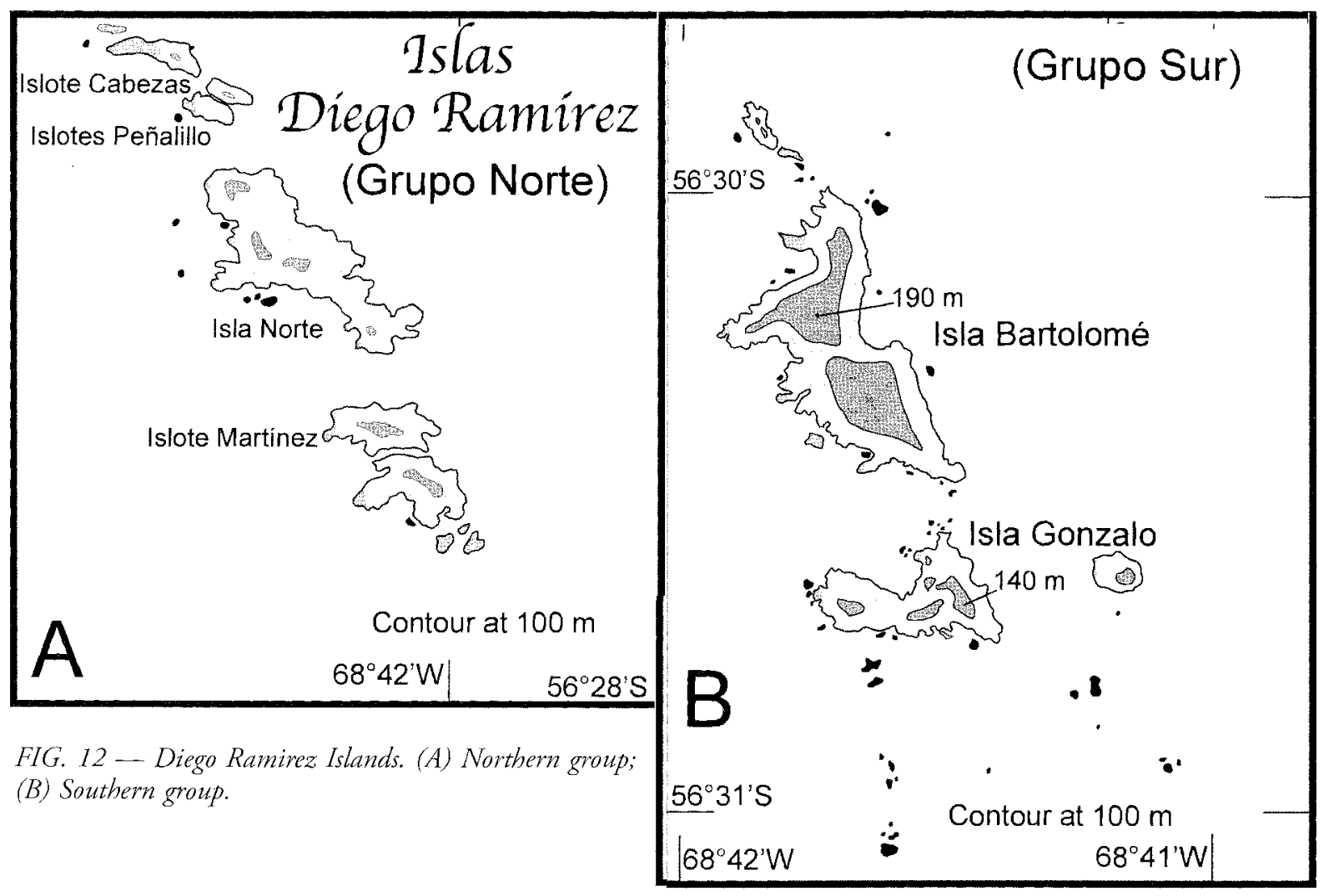

within it of an older Pacific Ocean seamount. Dating of events is not comprehensive but it is likely that the rocks suffered their most recent major metamorphic event in the Middle Jurassic $(169 \pm 16 \mathrm{Ma})$ and thus the original rocks were older, perhaps even late Palaeozoic. There appear to be two rock associations. One is more complex and regional, a tectonic melange of sea-floor rocks (sediments and basalts) that were initially at the leading edge of the rocks being subduced but later rose as the arc margin rose. The lithological affinities of the rocks are with those of the distant South Shetland islands and provide a link from South America, through South Georgia and around the margins of the Scotia Sea to the Antarctic Peninsula. The other association consists of metabasalts that represent the altered remnants of the original basalt of a subduced seamount. They are shallow-water pillow basalts with abundant vesicles and diverse characteristics, typical of the variety expected in the relatively shallow-water environment around a seamount. 


\section{South Georgia}

South Georgia is dominantly continental and lies on the eastern end of the North Scotia Ridge (fig. 13) which is separated from the South American Tectonic Plate by the Falklands Trough; however, Cunningham et al. (1998) place South Georgia on the South American Plate (their fig. 1(a), inset) whereas their fig. 1(b) indicates that gravity data would suggest that it lies on the Scotia Plate. Figure 11 follows the implication of fig. 1(b) of Cunningham et al. (1998). South Georgia was the site of the single "Antarctic" station for the first International Polar Year of 1882/83 — in Royal Bay (Headland 1992). The island is arcuate, concave to the southwest, and is the exposed part of a large continental basement fragment $380 \times 140 \mathrm{~km}$ marked by the isobath at $1000 \mathrm{~m}$ (Simpson \& Griffiths 1982) and with margin declining steeply to the $3000 \mathrm{~m}$ isobath. It seems that the exposed geology continues below sea level and that South Georgian rock types are typical of the entire block.

The $3000 \mathrm{~m}$ isobath delineates a series of three continuous but separately identifiable east-west oriented continental blocks along the North Scotia Ridge. The most easterly is the South Georgia Block and the other island-bearer is the Shag Rock Block to the west-northwest of South Georgia. Its rocks may be older than those of South Georgia.

South Georgia, like the islands on distant Campbell Plateau, on the mirror side of the East Pacific Spreading Centre, are fragments of the older continental crust of Gondwana left behind during the dispersion of the supercontinent. South Georgia and some other islands such as the Diego Ramirez Islands off southern Chile have been formed, or affected, by collision of Pacific Ocean sea floor with the continental rocks of South America. South Georgia is one of the most spectacular places on Earth but early explorers such as Cook were not full of praise as they referred to its forbidding appearance. It is an extremely rugged landscape.

The island can be divided into two distinct terranes. One is the major part and the second, smaller, area is that in the southern reaches of the island - the Drygalski Fjord Complex of the Salvesen Range and to the southwest.

The major part is composed of strongly folded Late Jurassic anci Early Cretaceous sedimentary rocks, mainly sandstones and volcanic rocks allocated to two major formations - Cumberland Bay and Sandebugten. These formed in a back-arc basin behind the southern Andes while subduction occurred on the southwestern side of the continent. The eastern side of the basin would have been parts of continental South America. The Cumberland Bay Formation which is the dominant exposed unit is Early Cretaceous in age (Aptian, 100-110 Ma; Thomson \& Tanner 1982) as judged by sparse bivalve and ammonite fossils, composed of andesitic volcaniclastic greywackes (Tanner 1991) up to $8 \mathrm{~km}$ thick. It was deposited in a marine environment by turbidity currents carrying sediments in units up to $5 \mathrm{~m}$ thick, from volcanic islands west of the current island. The composition of the greywackes is consistent with this scenario.

The Sandebugten Formation is significantly different in composition, has thinner sedimentary units and is composed of siliciclastic turbidites sourced from the more easterly side of the same sedimentary basin and thus more continental in character. It occurs mainly in the northeastern edge of the island around Barff Peninsula east of Grytviken. There is doubt about the age equivalence of the Cumberland Bay

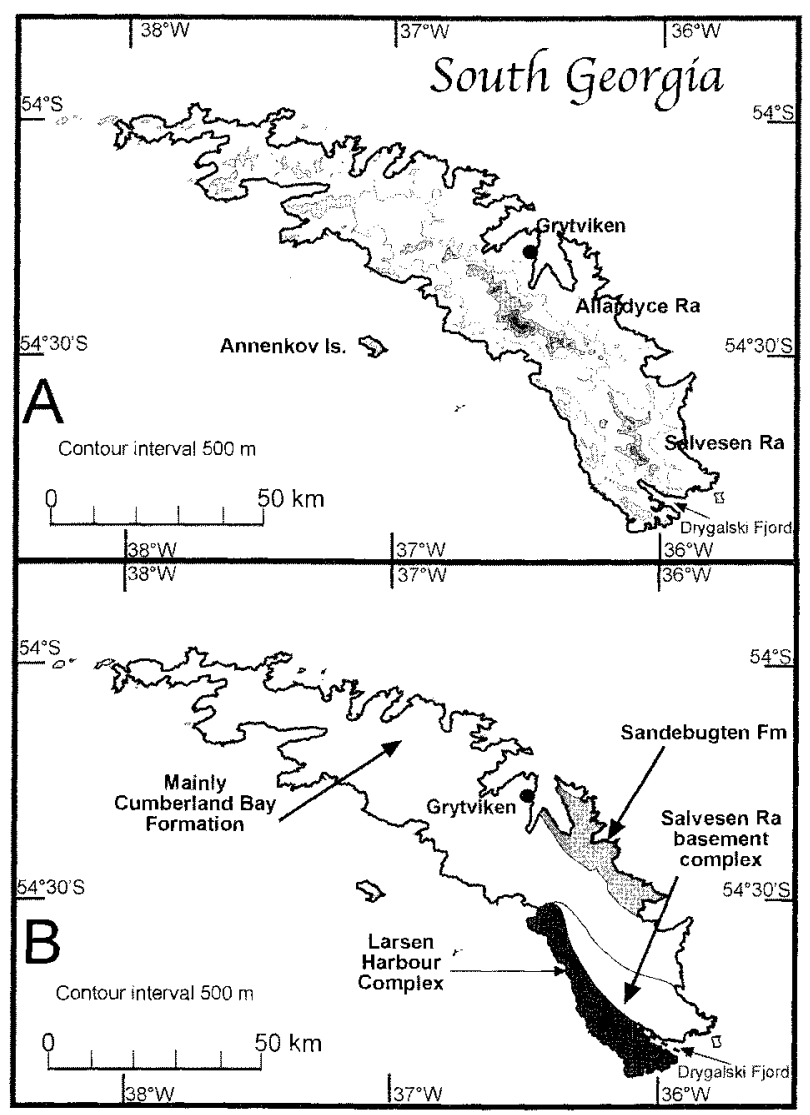

FIG. 13 - South Georgia. (A) Topography; (B) Geology.

and Sandebugten Formations as fossils are sparse especially in the latter formation. It is possible that the Sandebugten Formation is considerably older than the Cumberland Bay Formation.

There is uncertainty about the relationship between the two formations. A thrust is normally evident between them but whether this is simply a thrust or also marking the position of an unconformity is not clear. The two formations have suffered different post-depositonal histories. It seems (Tanner 1991) that deformation of the formations occurred separately before they came into thrust relationships, the deformation of the Sandebugten Formation occurring earlier, and that of the Cumberland Bay Formation coinciding with the thrusting during the mid-Cretaceous at 91-82 Ma (Thomson \& Tanner 1982).

The rocks of Annenkov Island are part of this sedimentary sequence but are only $3 \mathrm{~km}$ thick and have more abundant and diverse, but less definitive fossils which can be determined only as Early Cretaceous (Thomson \& Tanner 1982).

The Salvesen Range is composed of Gondwanan continental gneisses and schists of the Drygalski Fjord Complex that are intruded by granite, layered gabbros and basic dykes (Headland 1992). These are the oldest rocks on the island and are the remnants of the original continental block on which the sedimentary sequences were deposited.

Immediately to the west of the Salvesen Range is the Larsen Harbour Formation, the boundary coinciding with Drygalski Fjord. Here are pillow lavas, radiolarian cherts, sheeted dykes (as occur on Macquarie Island), gabbros and a complex association (ophiolite suite) typical of that constituting the sea-floor. These rocks have been plastered 
onto the continental rocks during a period of subduction along what was the Pacific Ocean margin. Instead of being consumed during subduction, these rocks have remained above sea level and may have over-ridden the older basement. As the Pacific sea-floor was subduced along the southern margin, folding was intensified and a slice of Pacific sea floor, instead of being led down, attached itself to the southern margin of the island through obduction. Thus South Georgia is basically a piece of South America with a slice of Pacific Ocean sea-floor attached as Drake Passage was formed.

The island has 13 peaks reaching over $2000 \mathrm{~m}$, the highest Mt Paget at $2934 \mathrm{~m}$ a.s.l. This ensures that, even if north of the Antarctic Polar Frontal Zone, the island is heavily glaciated and has been for many millions of years. The island bears the scars of this history. Ice reaches to $200 \mathrm{~m}$ on the southwest and $400 \mathrm{~m}$ on the other side of the island. The coast is thus heavily indented by fords; it is marked by high cliffs in most places.

The small area of Shag Rocks (also known by a variety of other names and locations in earlier history) is some $250 \mathrm{~km}$ northwest of South Georgia. The rocks, while continental, are different in type from South Georgia. These are greenschist facies metamorphic rocks that form small very rugged, triangular outcrops whose outcrop shape is controlled by internal structural fabric. Maximum elevation is $71 \mathrm{~m}$.

\section{THE SCOTIA ARC/SOUTH SANDWICH ISLANDS}

The Antarctic tectonic plate has almost no area subject to subduction, but there is one relatively small but important area where this aspect is well developed - the South Sandwich Islands - 10 volcanic islands and a notewotthy shoal (fig. 14) over an arcuate length of $350 \mathrm{~km}$; most have been active in the period of European visitation (Barker 1990). Barker (1990) recorded no Holocene eruption on Montagu Island, but Patrick et al. (2004) provided evidence for new activity in 2002 and continuing. Along Scotia Arc, the South Atlantic sea-floor is being subduced as a narrow slab in a "simplest of the world's arc-basin systems" (Leat et al. 2004) from the east below the South Sandwich Plate, accompanied by development of a volcanic arc with typical active volcanoes compositionally different from those elsewhere on the plate, and where deep earthquake activity is very pronounced. Even though the system is "simple", there are marked differences between the northern and southern ends of the arc. The northern end has a complex zone of seismic activity in contrast to the southern end which coincides with a transform fault. The eastern half of the Sandwich Plate and the Atlantic sea-floor converge at 67 (north)-79 (south) mm/year. The South Sandwich Trench, only some $100 \mathrm{~km}$ to the east of the volcanic arc, is over $8000 \mathrm{~m}$ deep in places, by far the deepest water in the Antarctic or sub-Antarctic. From the trench, the subduction zone dips at $75^{\circ}$ to the west at 60 $\mathrm{km}$ depth and can be traced to depths in the mantle of only $\sim 180 \mathrm{~km}$ and thus may be a geologically young feature, 15 $\mathrm{Ma}$ according to Leat $e t$ al. (2004). As expected in a volcanic arc above subducing crust and lithosphere, the rocks are generally pyroclastic in stratovolcanoes and with composition, while variable and including basalt, tending more into the andesite/dacite area with higher silica and volatile content, higher viscosity and evidence of more explosive volcanic activity. Eruptions include occasional release of very noxious

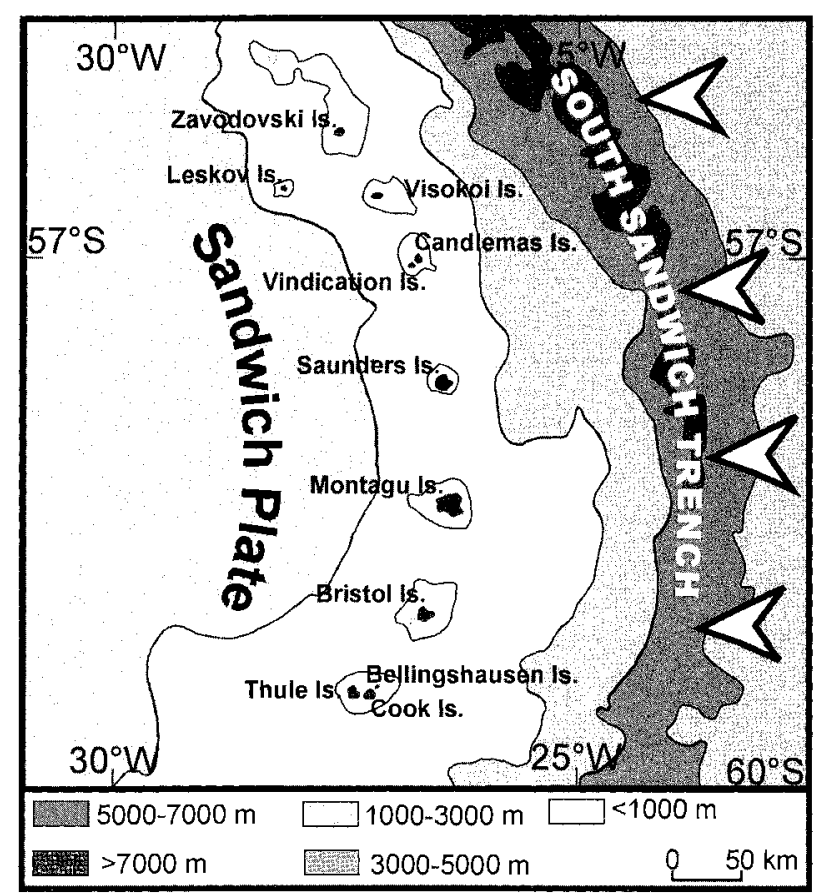

FIG. 14 - South Sandwich Islands. Direction of subduction indicated by large arrowheads.

gases, such as that encountered by Capt. C.A. Larsen from Zavodovski Island, and accompanied by explosive volcanism such as that which produced an immense raft of pumice from the previously unknown Protector Shoal at the north in 1962 (Gass et al. 1963, Sutherland \& Olsen 1968). Lavas from this site seem to come from a variety of sources, not a single parent (Leat et al. 2007). Over the last $200 \mathrm{ka}$, five eruptions have produced material that has been incorporated in the ice at Dome C in East Antarctica (Narcisi et al. 2005).

The slab of subducing South Atlantic sea-floor is older in the north $(83 \mathrm{Ma})$ than in the south $(27 \mathrm{Ma})$ and carries into the subduction zone the sediment that has accumulated on it; all sediment seems to be carried down (Leat et al. 2004) but that in the north has a higher carbonate content than that in the south.

The islands are roughly evenly spaced along the arc, about $70 \mathrm{~km}$ apatt. Leskov Island is about $50 \mathrm{~km}$ west of the axis of the other islands but this seems not to constitute evidence for any major anomaly. They are generally small, stark, barren features only 2-12 km across; the largest islands (Montagu and Saunders) are in the centre of the chain but there is no systematic variation in size along the chain. Visokoi, Montagu, Bristol and Cook islands are over 1000 $\mathrm{m}$ high, and Saunders Island $990 \mathrm{~m}$. Othets are substantially lower. Many are roughly quadrate but Leskov, Saunders, and to a lesser extent Thule, are arcuate and concave to the northeast or east. Protector Shoal reaches to within 27 $\mathrm{m}$ of sea level. The islands generally sit atop larger subsea volcanic foundations that may be $30-50 \mathrm{~km}$ wide.

Most islands are single volcanoes but Candlemas Island is divided by low sand flats with lagoons into two distinct volcanoes, a highly dissected younger cone in the northwest centred on Lucifer Hill, and an ice-covered older southeastern roughly symmetrical quadrate remnant. The younger lavas are andesite and dacite with low $\mathrm{K}_{2} \mathrm{O}$ in contrast with the porphyritic basalt of the older sequence. Leskov Island and Protector Shoal have high silica content lavas, $67 \%$ in the case of Protector Shoal. 
The age of most islands is Holocene but Montagu Island is dated at about $1 \mathrm{Ma}$, and Freezland Rock off the southwestern end of Bristol Island is $3 \mathrm{Ma}$. The entire arc has been estimated to be $5 \mathrm{Ma}$ (Barker 1990) and there seems to be no systematic variation in age along the chain.

The islands are all glaciated but vary greatly in ice cover, the difference depending on elevation, the proportion of the island that is elevated, and also on the heat flow from eruption in active volcanoes.

\section{Bouvetøya}

Bouvet Island (fig. 15) lies very close to the triple junction of three tectonic plates - South American, African and Antarctic. It is a little to the east of the triple junction near the Southwest Indian Ridge and a little south of the Ridge where it formed. It consists of a single dominant cone with summit caldera that is open to the north, possibly due to collapse of the northern flank of the volcano. The northern, western and southern margins are relatively straight. The north and west coasts are steep, the north due to collapse, and the west due to marine erosion, but elsewhere the slope from the caldera rim to the coast is uniform and thus the volcano appears to be more shield-like than a stratovolcano. The concavity left by the collapse to the north is now filled by the island's major glacier, the north-flowing Posadowskybreen. The rest of the island is covered by an icecap.

Because the island is so close to the triple junction and because the triple junction is believed to mark a long-lived plume marking the location where Antarctica, Africa and South America separated at some $120 \mathrm{Ma}$, the island volcanic rocks have been subject to many studies over a considerable interval, despite the difficulty of access (Verwoerd 1990a). Such studies have focused on questions of long-term evolution of hot-spot magmas especially at a point where there is no chance for involvement of a continental crust component.

The volcanic rocks are dated at slightly over $1 \mathrm{Ma}$ and they sit on older crust - some 4.5-5 Ma which has had a single, geologically short history of two intervals. The first sequence includes dominantly pyroclastics which have been altered by the influence of seawater on the erupting rocks. The second sequence formed above sea level away from marine influence and consists of subaerial basalt flows consistent with the appearance of a shield volcano.

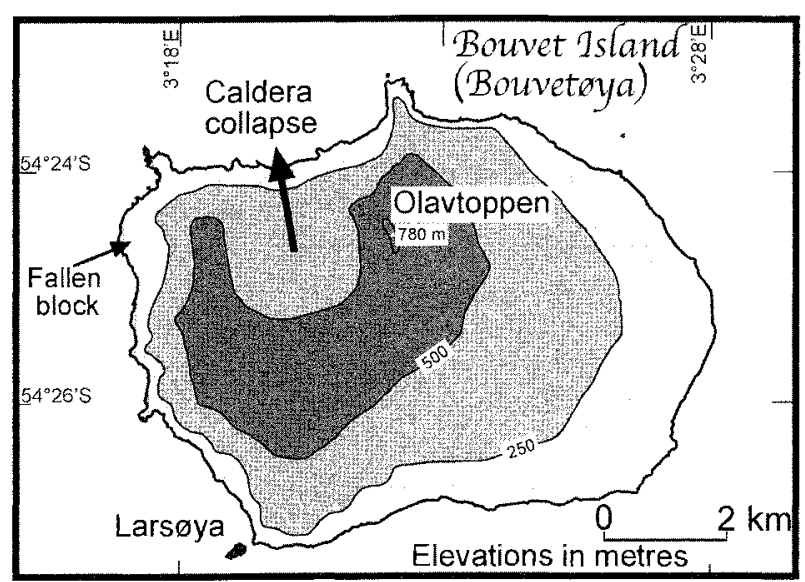

FIG. $15-$ Bouvetøya
The rocks lie close to the boundary between tholeiitic and alkaline fields (fig. 3) but slightly on the alkaline side, and while dominantly hawaiite extend as far as trachyte and alkali rhyolite. The rhyolites come from Larsøya at the southwestern point of the island and may be the youngest lavas of the area.

Between 1955 and 1958, a new beach and raised platform developed in the northwestern part of the island. Initially this was thought to be evidence of a modern eruption but re-examination shows that the rock is $0.45-0.5 \mathrm{~m}$.y. old and the block retained its internal cohesion and thus is due to simple downslope landslide movement and not a chaotic avalanche or modern eruption. Thus there is no evidence of modern volcanism even though there is mild fumarolic activity at the summit.

\section{Gough Island}

Gough Island (fig. 16A, B) lies at about $40^{\circ} \mathrm{S}$ and is thus closer to the equator than to the South Pole but is taken as sub-Antarctic for the purposes of the Scientific Committee on Antarctic Research (SCAR). It is the western end of three features - the others are McNish and R.S.A. Seamounts (fig. 16A) - which probably formed in the same way as Gough Island on a transform fault offset from the Mid-Atlantic Ridge, immediately south of Walvis Ridge. Between them, they constitute the Gough Fracture Zone (Chevallier 1987). There is some controversy about its geological setting but Gough Island seems to be similar to the Balleny islands except

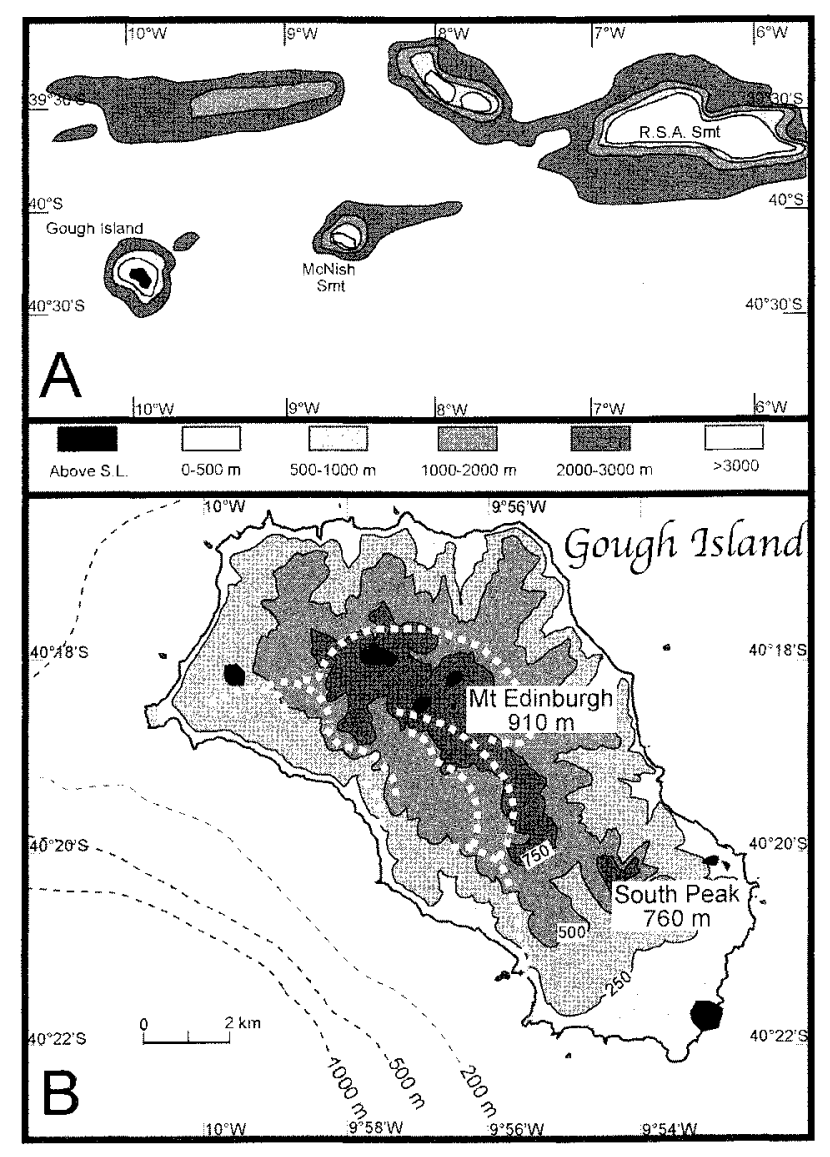

FIG. 16-Gough Island. (A) The regional setting. (B) Geology of Gough Island. Dashed white arcs indicate past calderas; black spots trachyte stocks. 
that two of the three island/seamount structures have already sunk below sea level thus leaving Gough Island as the lone island expression of the chain.

Gough Island is a single volcanic complex (Chevallier et al. 1983, Chevallier 1987, Maund et al. 1988) but with several episodes in its short history. When the entire edifice above and below sea level is considered, it is roughly circular in plan, but the island itself is elongate northwest-southeast, about $13 \times 6 \mathrm{~km}$, and slightly concave to the southwest. Chevallier (1987) recognised six stages in the volcanic history of the island. The oldest basaltic volcanism occurred at a little over $1 \mathrm{Ma}$ at about sea level and even included beach pebbles in the $70 \mathrm{~m}$ thick volcanic unit which shows evidence of explosive activity related to the interaction of sea water with the lava. This unit is exposed mainly on the northeastern side of the island. This was followed by basalt eruption above sea level from the main body of the volcano, $1 \mathrm{Ma}$ at the base of the sequence. These lavas cover a little over $50 \%$ of the surface of the island, mainly in the centre and southwest and are cut by a series of many radial dykes. After an erosive phase, a series of basalts were extruded about $3 \mathrm{~km}$ southeast of Mt Edinburgh at 0.5-0.6 Ma. This ended the basaltic phase of the island's history and is further marked by the collapse of the central caldera. During the interval $0.47-0.12 \mathrm{Ma}$, trachyte intrusion and extrusion filled many of the valleys fotmed after the basaltic phase and produced a series of trachyte plugs at various points around the island. This phase is centred on $\mathrm{Mt}$ Edinburgh $(910 \mathrm{~m})$, but these rocks are not cut by dykes. The latest eruption may have occurred as recently as 2300 years ago. The lava arose from a hot-spot source (Harris et al. 2000) but in contrast to Tristan da Cunha to the north, the lavas have risen to the surface without any mixing with sediments along the way and constitute a closed ftactional crystallisation system.

A marked feature of the island's volcanic centtes is the presence of a seties of arcuate, concave to the southwest, crater rims marking the positions of successive volcanic centres. It is likely that the southwestern side of volcanoes has suffered periodic collapse to the southwest generating the concave-to-the-southwest aspect of the island.

The island appears to be devoid of evidence of glaciation but it does show signs of progressive elevation during its growth (Gribnitz \& Kent 1989). Well-developed terraces occur at $3-4 \mathrm{~m}, 12-15 \mathrm{~m}, 30 \mathrm{~m}, 55 \mathrm{~m}, 75 \mathrm{~m}$, and at -23 and $-50 \mathrm{~m}$. It has been suggested that that at 3-4 m level relates to coastal erosion at $120 \mathrm{ka}$ (the last interglacial); those at $12-15$ and $30 \mathrm{~m}$ to the Middle Pleistocene; that at $55 \mathrm{~m}$ earlier in the Pleistocene, and the $75 \mathrm{~m}$ level somewhat older. Those below modern sea level may relate to intervals of lower sea level during the last glaciation.

\section{TECTONIC EVOLUTION OF THE INDIAN OCEAN AND FORMATION OF INDIAN OCEAN ISLANDS}

The Indian Ocean is unusual in having a series of submarine plateaux - large areas of ocean floor at intermediate depths and usually sampled as volcanic rocks formed subaerially and now sunk below sea level. These submarine plateaux support volcanic islands such as Heard Island and Îles Kerguelen on Kerguelen Plateau, and Îles Crozet on Crozet Plateau. Many of these islands, instead of having formed in one simple, short interval, have several episodes in their history over many tens of millions of years. Heard Island and Îles Kerguelen are consistent with this remark but there are exceptions.

The major tectonic development affecting the Indian Ocean began at 115-125 million years (early Cretaceous) when Africa-South America split off from Gondwana, opening up the Weddell Sea (Royet \& Sandwell 1989, Royer \& Coffin 1992). Shortly after this time, India (or what geologists term Greater India) began to move north from Antarctica from Gunnerus Bank, around Enderby Land to the Windmill Islands, thus initiating the Indian Ocean and permitting marine conditions to enter along this long coast. At about the same time, Africa/South America started to move apart allowing the Atlantic Ocean to form.

The northward movement of India also coincided with the initiation of a Large Igneous Province (LIP) which led to the formation of the Kerguelen Plateau (Duncan 2002, Frey et al. 2003, Quilty 2006). Because of its size, and as a high proportion of the Kerguelen Plateau lies below sea level, it is not well sampled except on the few islands and through deep sea drilling. Its history cannot be said to be well understood. It formed in three distinct, short-lived stages - at about 118-119 Ma, 100-95 Ma, and $35 \mathrm{Ma}$ and younger. Initially this included what is now Broken Ridge and all was attached to southwestern Western Australia. The first phase of disintegration was marked by vast outpourings of basaltic lava above sea level in a short interval followed by formation of soils, supporting vegetation of palms and ferns recovered by drilling of the Ocean Drilling Progtam (ODP) in 1988 (Mohr \& Gee 1992, Francis \& Coffin 1992). It may also have been a major source of carbon dioxide (Frey et al. 2003) with Greenhouse effects (Hansen et al. 2007). It is also likely that a thinned fragment of continental crust remains under Elan Bank, west of the main body of Kerguelen Plateau, and evidence of a continental component elsewhere on the plateau was encountered during drilling by ODP Leg 183 in 1999 (Ingle et al. 2002). The foundations of Kerguelen Plateau were laid. This piece of Kerguelen Plateau sank below sea-level at about $100 \mathrm{Ma}$ and has been accumulating pelagic sediment and volcanic material ever since, interrupted by times of increased ocean flow over the Plateau eroding some of the material alteady deposited and generating gaps in the geological record.

The second phase in Kerguelen Plateau formation occurred at about 100-95 Ma (late Cretaceous) when Central Kerguelen Plateau was formed; this supports Heard and McDonald islands which did not come into existence until much later. This part of the Plateau had a similar history to that of Southern Kerguelen Plateau, but is later. Until this time, part of the sea-floor spreading was occurring north of Kerguelen Plateau which remained on the Antatctic Plate, and a second coeval phase was active along the Western Australian coast opening up the eastern Indian Ocean. India kept moving north, generating sea-floor behind it and eventually colliding with Asia at about 40 Ma to form the Himalayas; this continues today.

This 100-95 Ma event probably coincided with the commencement of the northward migration of Australia, allowing the Indian Ocean to penetrate between Australia and Antarctica, but this sea-floor spreading initially was very slow and the southward projection of Tasmania and thinned oceanic crust south of it (now South Tasman Plateau but two separate fragments at the time) prevented any oceanic flow from the Indian to the Pacific Ocean south of Australia. The extension of this spreading ridge led to Australia and Antarctica being on separate tectonic plates. No circum-polar 
circulation yet existed but there may have been some flow through the Antarctic Peninsula region, some of which did not exist at $100 \mathrm{Ma}$. Sea-floor spreading between Australia and Antarctica accelerated to the modern rate of $7 \mathrm{~cm} / \mathrm{yr}$ at $55 \mathrm{Ma}$, and by $34 \mathrm{Ma}$ enough had occurred to allow circumpolar circulation to develop as the gateway between Australia and Antarctica grew wide enough.

At this time, the South East Indian Ridge (SEIR) between Australia and Antarctica began to split Kerguelen Plateau from Broken Ridge, generating new sea-floor between Kerguelen Plateau and Broken Ridge/Australia. The rift was now complete. Antarctica lay isolated over the South Pole while all other, now individual, fragments of Gondwana moved northward.

The northern part of Kerguelen Plateau formed at about $40 \mathrm{Ma}$ and Îles Kerguelen began a complex evolution of basaltic volcanism interspersed with intervals of forestation forming horizons of sediments with peat and fossil trees between lava flows. Volcanic activity was more or less continuous from about $26 \mathrm{Ma}$ (latest Oligocene) to very recently. The region is now quiet.

\section{Marion and Prince Edward islands - the Prince Edward Islands Group}

Marion and Prince Edward islands (fig. 17) sit atop a small submarine plateau - the Marion Plateau, mostly shallower than $200 \mathrm{~m}$ (and thus much exposed during the low sea level of the Last Glacial Maximum) some 55-60 km long, oriented north-northeast - south-southwest, which formed at about $54 \mathrm{Ma}$ (Verwoerd 1990b). They occupy positions at opposite ends of the plateau. They have a relatively short, dominantly volcanic history, with episodes of marine sedimentation, similar to the case in several other Indian Ocean volcanic islands. McDougall et al. (2001) regarded the volcano as related to hot-spot activity and recorded a track of a hot-spot (the Marion Hot-spot) over the last $120 \mathrm{Ma}$ from east of Madagascar to the current position of the islands.

Marion Island is slightly elongate east-west with a gentle dome shape, strong radial drainage and, in contrast to many islands discussed here, lacks a steep-cliffed margin.

Two main periods of eruption are recognised as (McDougall et al. 2001) "older grey lavas" and "younger black lavas". The former does not outcrop widely as it has been covered by the more recent black lavas. The "older lavas" were extruded between $450-30 \mathrm{ka}$ and alternate with sediment horizons many with glacial features. Five (perhaps as many as eight) glacial intervals are recognised and have been dated between dated flows. Flow dates are $454-413,363-323,244,201-156,110,92-81$ and 50 ka. The glacial intervals are then centred roughly on 450 , $275,190,75$ and $25 \mathrm{Ma}$, and have been interpreted as relating to well-known glacial maxima as defined by ice and sediment records elsewhere on Earth. Other possible glacial sediments are at 340,122 and $100 \mathrm{ka}$. The younger black lavas all seem to be $10 \mathrm{ka}$ and younger in age and are fresh and little-altered. The modern volcano on Marion Island erupted along an east-west fissure in 1980 and the most recent eruption was in 2004/2005. There is much evidence of activity in the last few thousand years from some 150 volcanic cones scattered widely around the island with little evidence of any structural pattern.

All lavas are attributed to the alkali oceanic island basalt group but lack any deep-seated xenoliths. Trachyte occurs on

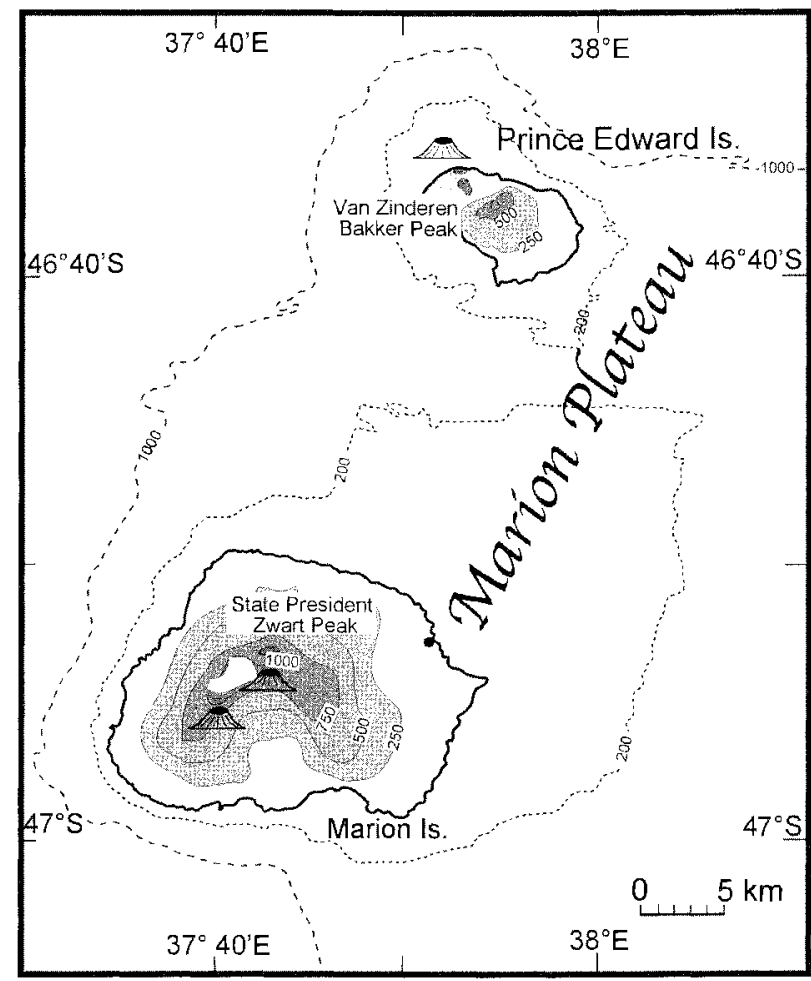

FIG. I7 - Marion Platedu with both Marion and Prince Edward islands.

Prince Edward Island. Gravity-controlled slope failure and landslides have had a major control on the modern landforms of the island leading to the rather uniform slopes.

Prince Edward Island is significantly smaller than Marion Island but was larger in the past. In contrast to the gentle slopes of Marion Island, it is marked by a $400 \mathrm{~m}$ escarpment at the coast on the northeast and southwest, but well inland elsewhere. The escarpment close to the coast marks the position of faults that caused collapse of the island margins along the northwest-southeast trend. Prince Edward Island has similar lavas to those on Marion Island but also includes more silicic lava (trachyte) with eruption mainly in the 200-110 ka interval. Verwoerd (1990b) suggests the lavas on the two islands come from different reservoirs. In addition to the main vent at the peak, there are about 15 cones widely scattered over the island; some of these are believed to have been active during the Holocene but no modern eruptions are known.

Marion Island has a small icecap above $1100 \mathrm{~m}$ and was seriously affected by glaciation during the Last Glacial Maximum; the moraines left by this glaciation are concentrated on the southeastern and northeastern extremities of the island. Prince Edward Island may have missed that glacial influence by virtue of being farther north and of lower elevation. Much of Prince Edward Island has disappeared, probably to the northwest, either by horizontal movement along a fault, or by a catastrophic slump that characterises many oceanic islands.

\section{îles Crozet}

This series of islands has a western and eastern group and all are incorporated in the Crozet Archipelago (fig. 18). They sit on Crozet submarine plateau on the eastern flank of the Indian Ocean Ridge which passes between South Africa and 


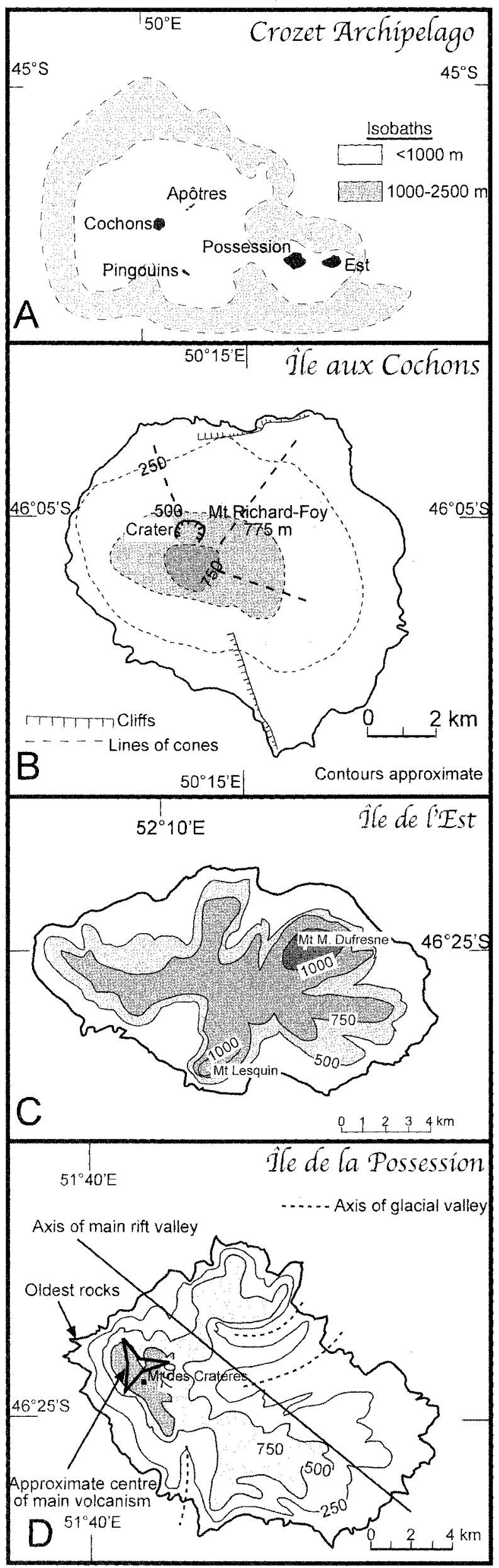

Antarctica (Nougier \& Thomson 1990a, Chevallier et al. 1983). The plateau could be as old as $54 \mathrm{Ma}$ but the islands are made of much younger volcanoes. The northeastern margin of the plateau has a marked $135^{\circ}$ azimuth and this is reflected in the orientation of the long axis of Île de la Possession and its central rift, the orientation of faults and cones on Île aux Cochons, and many other aspects of the islands. The western group of three islands (Île aux Cochons and the much smaller Île des Pingouins and Ilôts des Apôtres) and the eastern island group (Île de la Possession and Île de l'Est) are composed of many small volcanoes some of which have been active in the last few thousand years. The larger islands have all been affected by glacial activity which has sculpted many into their present landforms but there are no glaciers currently on the islands.

While the islands may be widely scattered on the submarine plateau, some phases of volcanic activity are consistent across the chain. Activity in the eastern group is from 9-1.3 Ma, but between 1 and $0.5 \mathrm{Ma}$ all islands in the archipelago have been active.

Île aux Cochons is a single young volcano, less modified than others in the area, and steeper on its western side. It has grown through two phases of activity - the first represented by $400 \mathrm{~m}$ of phreatomagmatic breccias (caused by the explosive interaction of lavas with ground water) and interbedded $1 \mathrm{~m}$ thick basalt hows exposed in cliff sections in the northern and southern parts of the island. This phase $(1-0.5 \mathrm{Ma})$ was followed by faulting which allowed emergence of the second phase $(0.2 \mathrm{Ma}$ - present) of some 60 small cones and flows radiating from a crater at the summit (Mt Richard-Foy). The younget cones commonly are arranged in four radiating linear series along the earlier, post first-phase faults. Two of the directions $\left(70^{\circ}\right.$ and $\left.160^{\circ}\right)$ are parallel to faults that control some of the coast directions indicating that the coast is also patrly fault-controlled. These phases are the youngest recorded in the archipelago and other volcanoes have evidence of earlier eruption. The lavas are all alkali basalts.

Île des Pingouins and Ilôts des Apôtres are $50 \mathrm{~km}$ southsoutheast and $15 \mathrm{~km}$ northeast of Île aux Cochons. Both are remnants of volcanoes but have been severely reduced in size by block faulting or erosion. Île des Pingouins displays coarse breccia, flows and hyaloclastites (glassy fragmental lavas) in cliffs, and Ilôts des Apôtres consist of two small islands and 12 rocky islets arranged along the $70^{\circ}$ azimuth.

The eastern group comprises two older and larger volcanic islands (Île de la Possession and Île de l'Est) which may still technically be active. Île de la Possession is a stratovolcano which has dates of $8.1-0.53 \mathrm{Ma}$ and was formed during five or more phases of volcanic activity. The oldest rocks occur on the western tip of the island and consist of fossiliferous hyaloclastite with mussels and pectenids (Chevallier et al. 1983) deposited in a shallow marine environment. Preservation is too poor to allow accurate radiometric dating. The second phase provided the $8.1 \mathrm{Ma}$ date and was the main stratovolcano-building event that developed the basement of the island. The lava source probably was on the western side of the current island and generated lavas and interbedded pyroclastics until $2.7 \mathrm{Ma}$. The centre of the entire activity was to the west of the island. Immediately following this

FIG. 18 - (A) Crozet Archipelago; (B) Ile aux Cochons. (C) Ille de l'Est. (D) Ile de la Possession. 
phase, the volcanic pile was intruded at about $1.3 \mathrm{Ma}$ by extensive ring dykes and lesser cone sheets. The third phase consists of coarse conglomerates and other detrital material $10-50 \mathrm{~m}$ thick, overlain by lavas and sills. The lavas were fed by large radial dykes with a centre on the western side of the island. Dates derived from this phase are in the range 1.03-0.72 Ma. The island then underwent a period of rifting along $135^{\circ}$ to produce a rift $5 \mathrm{~km}$ long and $12 \mathrm{~km}$ long, and extends beyond the island as part of re-activation of a much older feature. Volcanism from this phase occurred between $0.7-0.53 \mathrm{Ma}$ and produced a 10 -m-thick plateau of basalt which covers much of the island. Rocks of this phase were then modified by glaciation which produced three large U-shaped valleys. The final phase recognised so far consists of the products of some 30 small cones older than $5.5 \mathrm{ka}$. Structural modification of the entire complex during this time is probably related to regional rather than local tectonism.

Île de l'Est is oriented east-west, at variance with the dominant $135^{\circ}$ trend so common in other features of the archipelago. Its basement consists of a metamorphosed 8.75 $\mathrm{Ma}$ complex of gabbro (and related rocks) which has been cut by dykes, many with orientations of $110-135^{\circ}$ (as widespread on the Archipelago and parallel to a nearby prominent sea-floor magnetic anomaly) as sources of lava for the succeeding four phases of volcanism which produced a 1000-m-thick sequence of agglomerates and lesser flows. Successive volcanic episodes were focused on the centre of the island to produce a high stratovolcano. The second phase began with a basal conglomerate succeeded by agglomerate and thin flows, followed in turn by thick agglomerate and basalt lava flows. The final phase consists of a few scoria cones dominantly in the eastern end of the island. Île de l'Est lavas appear to be the most diverse of those known from the Archipelago and the basement contains the only such rocks known from the Archipelago.

The island has been subjected to severe glacial erosion which has produced a series of radially arranged valleys and a major cirque complex with related moraine on the southwestern side.

\section{Amsterdam and St Paul islands}

Each of these islands, some $100 \mathrm{~km}$ apart, lies about $1.5 \mathrm{~km}$ southwest of the axis of a northwest-southeast oriented spreading ridge in the western Indian Ocean and thus is important for the study of ridge-crest volcanism. A northeastsouthwest oriented transform fault appears to pass between the two islands. The islands are less than $0.4 \mathrm{Ma}$ in age and the Amsterdam-St Paul Plateau less than $5 \mathrm{Ma}$ (Doucet et al. 2004). The hot-spot that was parent to the Plateau is now believed to lie below Boomerang Seamount.

Amsterdam Island (Nougier \& Thomson 1990c) is a dormant stratovolcano bounded on its northwest and southwest flanks by fault-controlled cliffs (fig. 19). The controlling cliffs are partly parallel to the axis of the parent ridge crest. Nougier (1982) recognised two volcanic phases in the history of the island. The older volcano (perhaps 0.1 $\mathrm{Ma}$ ) was the main construction event and is referred to as the Fernand palaeo-volcano with its feeder dyke at Pointe d'Entrecasteaux, a small protuberance on the southwestern side of the island. The eruption products of the older volcano are porphyritic basalt with plagioclase and clinopyroxene phenocrysts, and some aphyric lavas.
The younger volcano (the Dives neo-volcano) had an eruption centre about $2 \mathrm{~km}$ east of the earlier Fernand palaeo-volcano. Initial lava flows were to the west but later to the north with flows to about $3 \mathrm{~km}$ long. Eruptions always seem to have been non-explosive. The age of the Dives neo-volcano is unclear but seems to have been in the last few tens of thousands of years. There are some 20 later small scoria cones, some of which may have erupted in the last 100 years producing glassy lavas. The dominant lavas contain plagioclase phenocrysts that are richer in the anorthite end member, suggesting an evolution in lava type towards the Ca end member. Such lavas are aphyric farther away from the source.

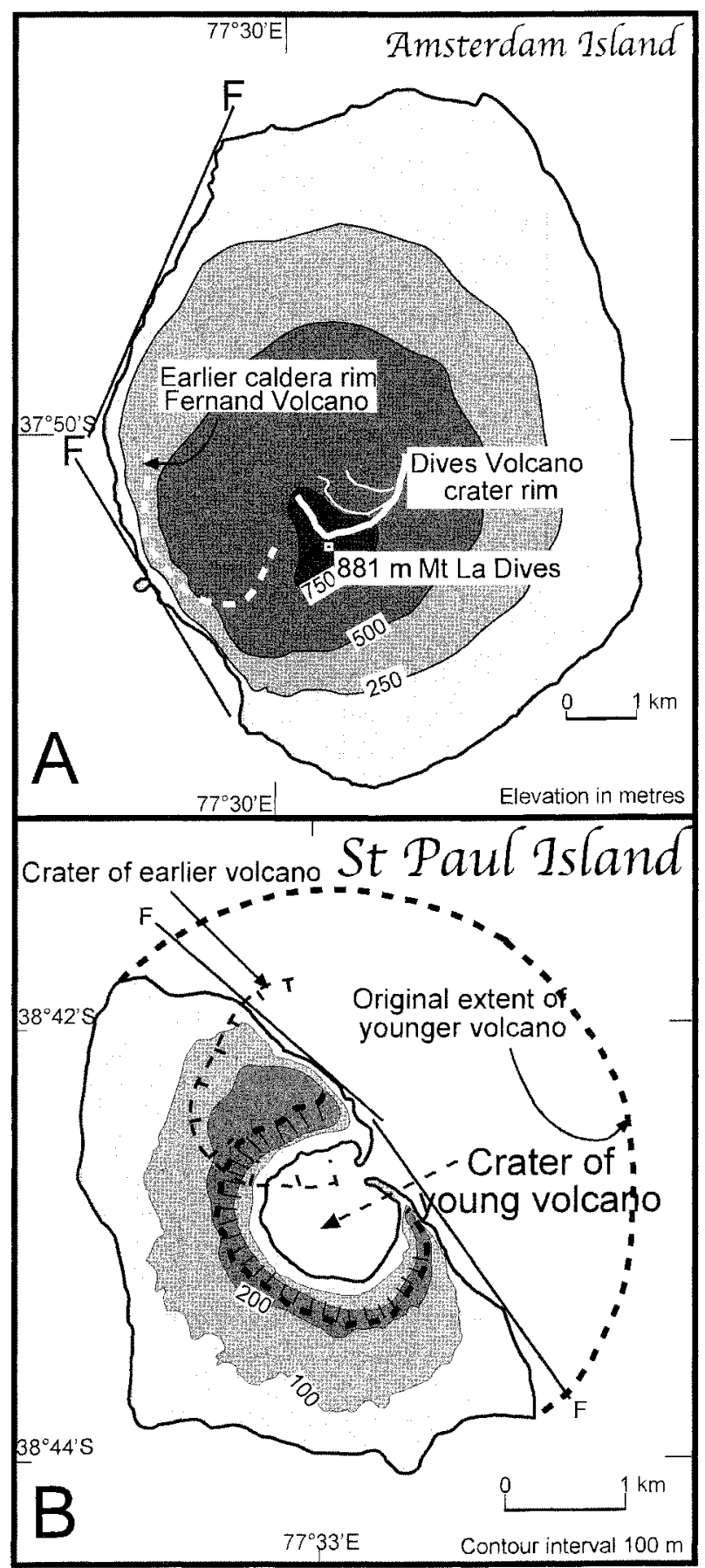

FIG. 19 - Amsterdam and St Paul islands. (A) Amsterdam Island; (B) St Paul Island. F = fault. 
The avifauna suffered badly during human occupation and the story of decline and extinction, including one of the endemic species (Anas marecula Olson \& Jouventin, 1996) is provided by Worthy \& Juventin (1999).

St Paul Island has a faulted northeastern margin, along which faulting has removed an estimated $3 \mathrm{~km}^{2}$ of the island's original area. It has a central circular crater about $1 \mathrm{~km}$ wide and $300 \mathrm{~m}$ deep, now up to $80 \mathrm{~m}$ below sea level and open to the sea via a shallow gap. The original volcano is visible in the northeastern cliffs but the rest of the island is the result of a younger volcano. Products of the earlier volcano consist of yellowish pumice deposits, originally basalt, which are cut by rhyolite dykes but these rocks are highly altered by weathering. The rhyolitic dykes contain some quartz and sanidine and are described as alkaline rhyolites. The newer volcano consists of basalt flows and fragmental material, but lacking pillow lavas that would indicate submarine eruption. Lavas are diverse basalts. Volcanism is younger than $100 \mathrm{ka}$ and the island still retains hot springs and fumarolic activity.

Overall, the islands are of tholeiitic basalt but there is a difference in lava composition between the two islands with St Paul having lavas with about $51.5 \% \mathrm{SiO}_{2}, 4 \% \mathrm{Na}_{2} \mathrm{O}$ and $1.02 \% \mathrm{~K}_{2} \mathrm{O}$, in contrast with those from Amsterdam Island with $49 \% \mathrm{SiO}_{2}, 2.5 \% \mathrm{Na}_{2} \mathrm{O}$ and $0.6-0.7 \% \mathrm{~K}_{2} \mathrm{O}$. The $\mathrm{Na}$ and $\mathrm{K}$ are lower in the Amsterdam Island lavas but the ratio between them is the same.

Recently, the 1100-m-high, volcanically active, Boomerang Seamount (3743.3'S; $77^{\circ} 49.5^{\prime} \mathrm{E}$ ) was discovered on the Amsterdam-St Paul Plateau, $18 \mathrm{~km}$ northeast of Amsterdam Island at the intersection of a transform fault and spreading ridge. It has similar lava composition to that of St Paul volcanics (Johnson et al. 2000).

\section{îles Kerguelen}

Îles Kerguelen (fig. 20) have, in common with Heard Island, a multi-phase history including a relatively long and dominantly volcanic story interspersed with intervals of sediment formation with peat and fossil leaves and wood and some marine incursions. The area is almost a sub-continent in diversity, composition and complexity (Giret \& Lameyre 1983, Nougier \& Thomson 1990b). Because of this long history and diverse rock assemblage, the islands may provide information relevant to understanding the evolution of Large Igneous Provinces (LIP) such as Kerguelen Plateau (probably the second largest submarine plateau) which appear to occur only in Cretaceous and younger times.

Iles Kerguelen is complex with a main island (GrandeTerre) some $6500 \mathrm{~km}^{2}$ in area and 300-400 other small islands and rocks. The basement of the island can be divided into two major provinces - a northern province (Transitional Tholeiite, fig. 20), and a southern, generally younger province (Alkali Basalt) which may overlie a continuation at depth of the Transitional Tholeiite. The provinces are separated on the surface by a northwest-southeast arcuate boundary. The Transitional Tholeiitic province is composed of flat-lying plateau basalt lavas generated by four shield volcanoes (1-4, fig. 20) centred on an arc parallel to the arcuate boundary. These have ages mainly in the range 38-23 Ma with a few younger dates. The complexes are both plutonic and their volcanic equivalents. There is no evidence, as yer, of a basement with superposed volcanics; plutonic and volcanic rocks are of essentially the same age ranges. The plutonic

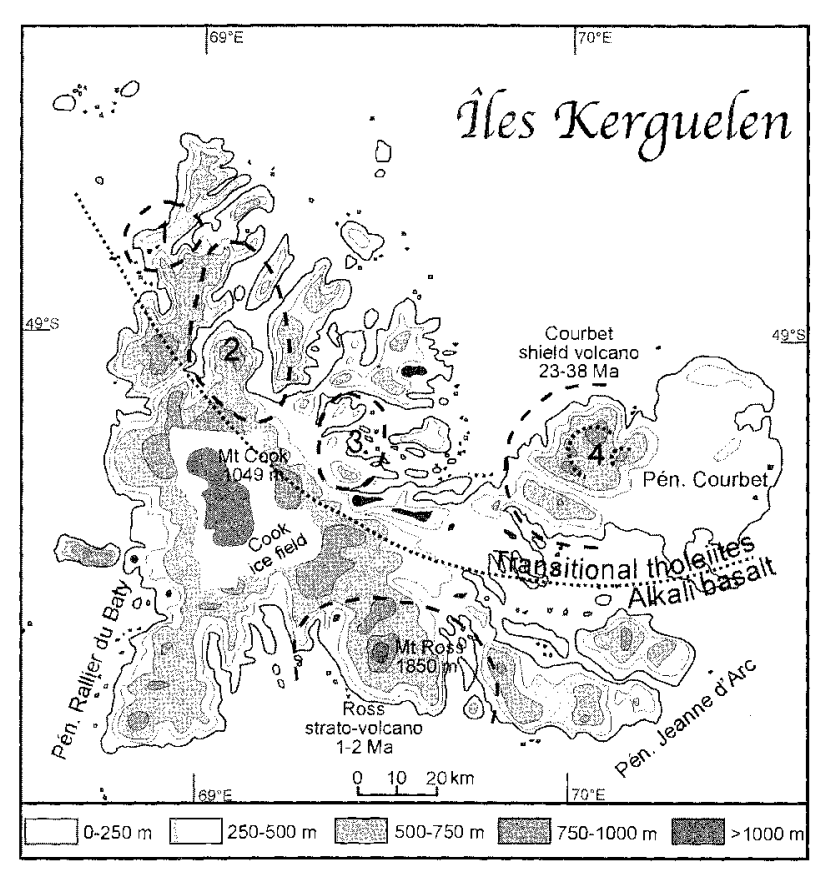

FIG. 20 - Iles Kerguelen. 1-4 in dashed circle = older shield volcanoes of tholeititic province.

phases, concentrated on western Péninsule Courbet, at Péninsule Rallier du Baty and north of the Cook Icefield include alkali-granite, nepheline syenite and biotite gabbro to emphasise the sub-continental aspect. Ages obtained from the plutonic rocks are older than those from the intruded volcanics and it may be that emplacement of the plutons has reset the original ages of the volcanics (Nougier \& Thomson $1990 \mathrm{~b})$. The Alkali Basalt province is younger, generally 23-17 Ma, and the ages of the volcanics are consistent with those of the associated plutonics. The basalts have a total thickness of some $1000 \mathrm{~m}$ with individual flows 3-10 $m$ thick and interbedded with pyroclastics, rare marine horizons (Fletcher 1938, Fleming 1957), and non-marine members with lignite and silicified tree trunks (Cookson 1947). Volcanism seems not to have been continuous but episodic with products separated by angular unconformities, breccias and sedimentary horizons.

The basement complexes have been intruded by a large number of dykes with strong northwest-southeast and northeast-southwest orientations over the northwestern part of the island, but as concentric ring-dykes around Mt Ross in the central south.

A major plutonic complex was intruded into Péninsule Rallier du Baty at 9-5 Ma and includes quartz-rich syenite and granite, rocks much higher in silica than found in most oceanic islands. It appears to have escaped intrusion by large numbers of dykes that cut the basement.

The major young volcano in the central southern part of the island is Mt Ross - a pyroclastic stratovolcano $15 \mathrm{~km}$ in diameter with summit caldera $5 \mathrm{~km}$ wide and numerous parasitic cones less than $1 \mathrm{Ma}$ suggesting that they were the end stage of eruption. Mt Ross dates are 2 $\mathrm{Ma}$ and younger. To the west of Mt Ross lies Péninsule Rallier du Baty where hot springs and fumaroles are active. Ages of plutonic rocks are 9-5 Ma and there is evidence of Holocene trachyte flows.

Uniquely among oceanic islands, Îles Kerguelen has provided xenoliths of granulite from several localities on Péninsule Courbet and Péninsule Jeanne d'Arc. These 
granulites, high metamorphic grade, normally indicative of lower continental crust, include sapphirine. Estimates of the P/T regime are discussed by Gregoire et al. (1994) who suggest a temperature of about $900^{\circ} \mathrm{C}$ and pressure equivalent to that at about $35 \mathrm{~km}$. This gives some indication of conditions that may exist beneath these large submarine plateaux.

The highest part of the island is generally to the west where the Cook Icefield - a remnant of a once much larger icecap - sits on Le Dome (1049 m) but Mt Ross at the south is the highest peak at $1850 \mathrm{~m}$ and several peaks are close to $1000 \mathrm{~m}$. The eastern part of the island is generally of lower relief and was the recipient of sediments deposited by river and glacial action. Péninsule Courbet is composed largely of glacial outwash and moraine. Glacial striations are common where the lithology is appropriate.

The complex of islands is a highly radially-glaciallydissected landscape forming a highly indented coast with abundant peninsulas and fjords. An icecap of $600 \mathrm{~km}^{2}$ still exists on Le Dome $(1049 \mathrm{~m})$ on the central western part of the island.

\section{Heard Island and the McDonald Islands}

Heard Island (Barling 1994, Quilty \& Wheller 2000, Green \& Woehler 2006, Stephenson et al. 2006) has a more complex history than oceanic islands in general. The island (fig. 21A) consists of two separate parts - the island proper dominated by the volcano Big Ben $(2745 \mathrm{~m})$, and Laurens Peninsula to the northwest with Mt Dixon at its centre. The island is south of the Antarctic polar Frontal Zone and, together with its height, ensures it is heavily glaciated. Three major, and several minor, phases can be recognised in its history over the last $45 \mathrm{Ma}$. When Central Kerguelen Plateau sank below sea-level at approximately $100 \mathrm{Ma}$ (Wise et al. 1992, Quilty 2006), it began to accumulate pale pelagic sediments - nanno/foram ooze - mainly formed of the skeletons of two groups of calcareous planktonic organisms - coccoliths and foraminifera (Quilty et al. 1983). The sediments also contain dark horizons probably representing inrervals of volcanic activity. These sediments solidified to form limestone inferred to be the basement of the island even if exposed only on the western region of the island. These sediments have been severely disrupted by faulting and tilting between fault blocks but the age of the faulting is not known. Little is known of what happened for a long time but volcanism was active somewhere in the region through much of the interval. Dolerite intrusions form sills in the older limestone and all has been intruded by trachyte dykes. This sequence was then subject to erosion to form a widespread unconformity. At about 9 million years (Truswell et al. 2005), a mass of volcanic rocks - the Drygalski Formation to about $350 \mathrm{~m}$ thick accumulated on this unconformity, but the parent volcano was not on Heard Island. The Drygalski Formation contains a mixture of pillow lavas, tuffaceous sediments and marine siltstone but has not been subjected to serious study. It contains a few marine molluscs - particularly the bivalve Austrochlamys heardensis (Fleming, 1957) (Quilty et al. 2004) which also is known to the east of the island. The land at the time was host to at least two terrestrial vegetation types - open heath with grasses and fern/lycopod/angiosperm but lacking trees. The Drygalski Formation was laid down on the older limestone and in turn formed the foundation for the modern volcanoes of Big Ben and Mt Dixon on Laurens Peninsula.

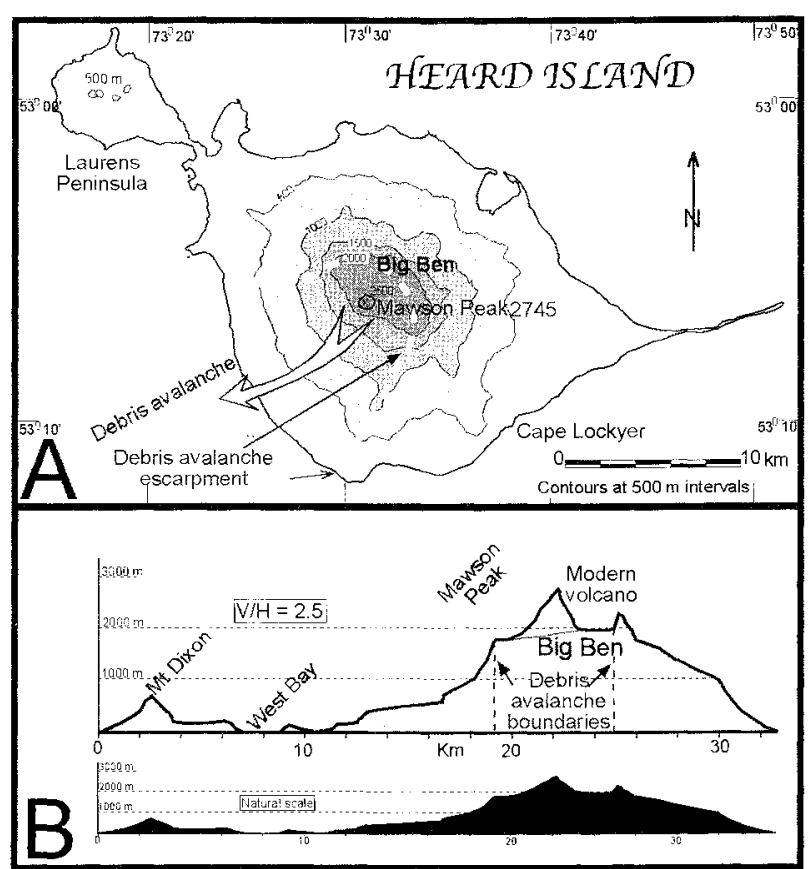

FIG. 21 - Heard Island. (A) Topography and volcanic features. (B) Profle through island at both natural and exaggerated scales.

Big Ben defines the shape of the island and is currently mildly active through the small volcano of Mawson Peak. The age of Big Ben is unknown but likely to be 1 million years or less. Surrounding Big Ben on the coastal fringes of the island are several small cinder cones. The main lavas of Big Ben are highly porphyritic basanites, alkali basalts and trachybasalts with abundant phenocrysts of olivine and clinopyroxene with high titanium content. Ash content of the complex is low except at the smaller marginal cones. Mt Dixon is much younger and an age of about $10 \mathrm{ka}$ has been obtained from lavas under the volcano. It is trachytic with low phenocryst content. It may be only dormant. The island lavas are similar to other oceanic island lavas common in the Indian Ocean probably resulting from deep-seated plumes or hot-spots. Big Ben and Laurens Peninsula lavas are distinct but emanate from a common parent source probably by differentiation of the Big Ben lavas from the primary source which is represented at Laurens Peninsula.

The flanks of Big Ben are marked by steep, radial glaciers flowing between raised rock barriers or buttresses that are prominent features of the island. The eastern end of the island is an elongate spit due to oceanographic distribution of debris from the volcano and from that deposited by the melting of the terminations of the glaciers. Passage of the detrital material around the island provides a basis for shorter longshore drift deposits that enclose several lakes near the edges of the island.

At some stage, the southwestern side of the island has collapsed into the ocean, leaving a major scar (fig. 21B) and a debris avalanche amphitheatre in which the currently mildly active Mawson Peak grew.

Approximately $40 \mathrm{~km}$ to the west of Heard Island lies McDonald Island (fig. 22A). The McDonald Island lavas differ from those of Heard Island, being phonolitic with high $\mathrm{Na}_{2} \mathrm{O}+\mathrm{K}_{2} \mathrm{O}$ (about 15.5-16.5\%). 


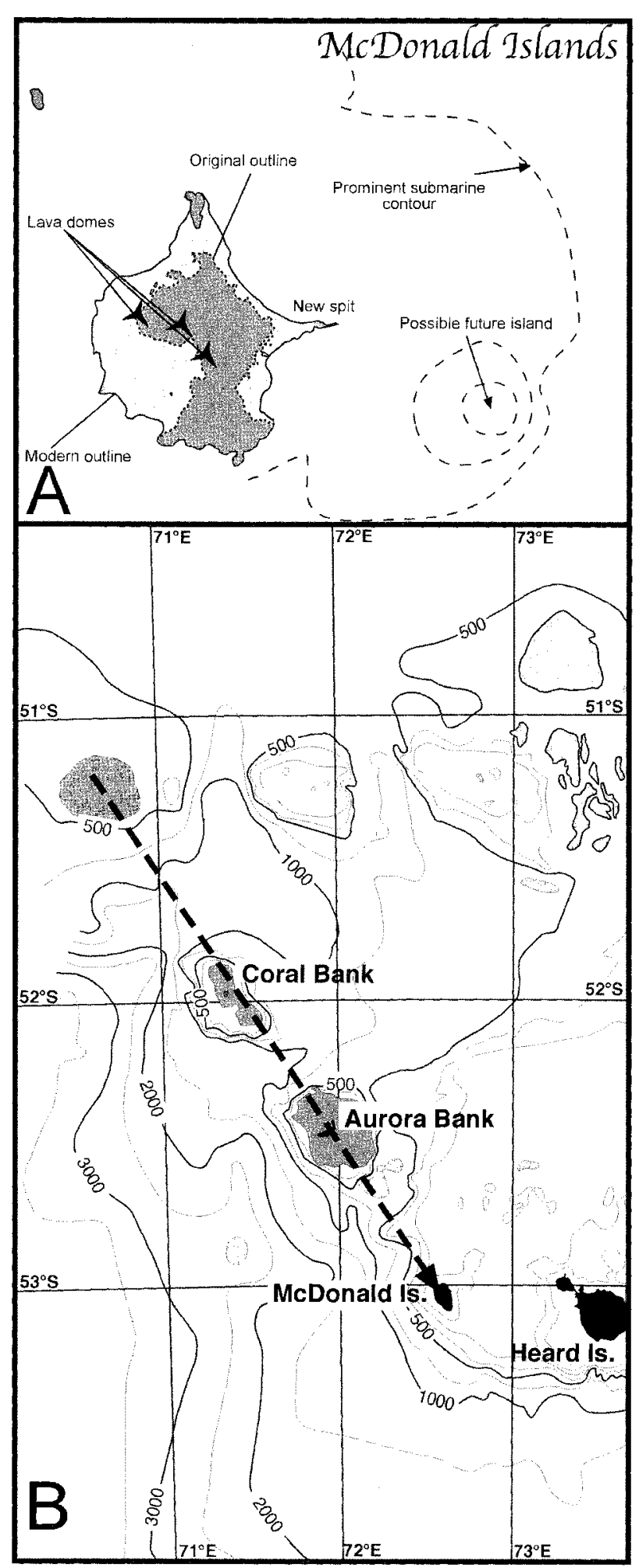

FIG. 22 -- Features of McDonald Island. (A) Changes in outline consequent on 1992 and successive emptions. (B) Possible track of mobile hot-spot leading to McDonald Island.

After a period of quiescence for 75-100 000 years, it was re-activated in December 1992 (Quilty 1995). Several broad lava domes with short radial flows are visible. This activity has continued and changed the face of the island, generating a spit (mimicking that of Heard Island) on the eastern side, and beaches, now inhabited by abundant penguin and seal populations. To the east of the island, several submarine features are visible. There is a large circular submarine contour, probably marking a constant depth of the volcanic construction. To the southeast of the island on this feature, there is a very shallow area commonly with a small cloud over it. It is possible that submarine eruption occurs here and that a new island will emerge above sea level in the near future. McDonald Island raises other questions, especially as they relate to the mobility of volcanic 'hot-spots' (fig. 22B). McDonald Island appears to be stationary at the southeastern extremity of a hot-spot chain which has formed successively three seamounts to the northwest - including Coral and Aurora Banks suggesting that, if all are due to hot-spot activity, the hot-spot is migrating.

\section{CONCLUSIONS}

The islands of the sub-Antarctic differ in origin from those most commonly illustrated in popular literature and can be classified into groups of similar origin (table 2).

It has not been possible to treat the geology of all islands to a common depth because all have not been studied to the same extent. Much remains to be done.

Many of the islands are very young, commonly $<1 \mathrm{Ma}$. It is unlikely that the spectrum of ages is any more unusual now that at any time in the past $10 \mathrm{Ma}$. In turn it is highly likely that, at any time in the past $10 \mathrm{Ma}$, a collection of islands with the same range of ages would exist. It thus is probable that the islands, other than those of continental material or on major submarine plateaux, have a very short life span, probably of the order of 1-2 m.y. While the islands may be ephemeral, the larger scale features of which they are the exposed portion, have a longer life as seamounts or guyots.

Despite their diverse origins described above, the subAntarctic islands can be grouped into categories with similar origins and histories. With the exception of Macquarie Island, the volcanic islands grew from normal sea floor or ocean plateau depths, are briefly above sea level and most will, in time, sink below sea level. The islands and their categories are summarised in figure 23.

Those involving continental crust. Many of the islands and islands groups are either of continental rock (South Georgia), the result of collision between continental margins and oceanic crust (Diego Ramirez), or sit on submerged thinned continental crust (the islands of the Campbell Plateau Antipodes, Auckland and Campbell islands). In each of these cases, the islands are close to a continental margin.

Those associated with a subduction zone. This category includes only the 10 islands of the South Sandwich Islands group. These islands have much in common with those associated with subduction zones elsewhere.

Those related to transform faults. The most prominent of these in the sub-Antarctic are Gough Island and the Balleny Islands where the island is part of a linear series, whether or not others of the series are emergent or have sunk below sea level. Peter I Island may belong here.

Those on submarine plateaux. This group is dominantly in the Indian Ocean and includes Îles Kerguelen, Heard and McDonald islands, the Crozet Archipelago and Amsterdam Island and the Prince Edward Islands. There is current debate on the role of thinned, submerged continental crust (cf. Campbell Plateau) as forming the basement to a volcanic veneer on such plateaux. Another view is that the submarine plateaux formed as a thick volcanic pile in the oceanic 
TABLE 2

Classification of sub-Antarctic islands

\begin{tabular}{lll}
\hline Island & \multicolumn{1}{c}{ Setting } & \multicolumn{1}{c}{ Age (Ma) } \\
\hline Amsterdam/St Paul & Submarine plateau & $<0.45$ \\
Antipodes Island & Submerged continental plateau & $<0.5$ \\
Auckland Island & Submerged continental plateau & Continental/mid Te \\
Balleny Islands & Transform fault & $<2 ?$ \\
Bouvetøya & Triple junction & 0.5 \\
Campbell Island & Submerged continental plateau & K-0 \\
Îles Crozet (Possession) & Submarine plateau & $9-0$ \\
Diego Ramirez & Continental - collision & Continental \\
Gough Island & Transform fault & $<1$ Ma \\
Heard \& McDonald Is. & Submarine plateau & $40,9,1-0:$ Active \\
Îles Kerguelen & Submarine Plateau & $39-25 ; 23-17$ \\
Macquarie Island & Raised sea floor & 9 \\
Marion \& Pr. Edward Is. & Submarine plateau & $0.45-$ Recent \\
Peter I Island & Transform fault, single & $<0.33-0.11$ \\
Scott Island & Single, simple'/transform & "very young" \\
South Georgia & Continental crust & Continental \\
South Sandwich Is. & Subduction related & $3-0:$ Active \\
\hline
\end{tabular}

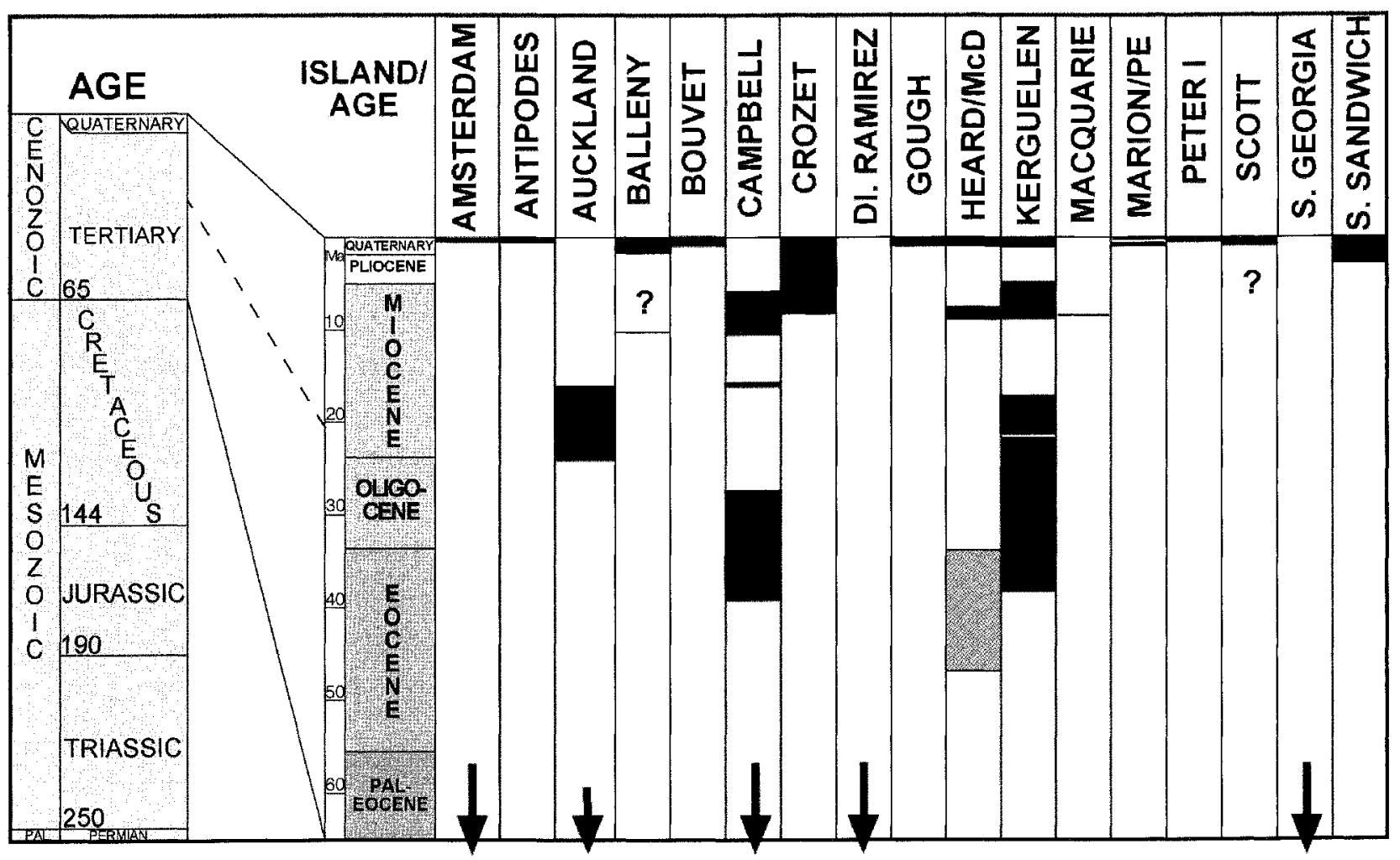

FIG. 23 - Summary of the ages of sub-Antarctic islands. 
environment, far from any continent and evolved through several stages over many tens of millions of years. The islands themselves are volcanic and are currently or recently active.

Raised sea-floor. Macquarie Island is unique among the islands discussed in that it formed at a mid-ocean ridge and sank into deeper waters. Because of tectonic activity, it now is situated at the boundary between the Pacific and Indian-Australian tectonic plates, and tectonic interaction between the plates has brought to the ocean surface a piece of the ocean floor. On all other islands described here, the rocks and their structural and mineralogical characteristics formed above sea level i.e., on an emergent island - but on Macquarie Island they formed on the sea floor. Macquarie Island is also different in that it is still rising in contrast to others that are subsiding.

'Simple', single-phase islands. These seem to stand alone and formed in a single episode of volcanic eruption. This group includes Scott Island and Peter I Island, each of which has a small plateau beneath it, and could also be classified as a submarine plateau island. Scott Island could also be assigned to a transform fault association such as for Balleny Islands.

Triple junction. Bouvetøya is not easy to classify into a broader category. It sits close to a triple junction that has been interpreted as marking a long-term hot-spot site. It is not at the triple junction at present and may be an island, similar to Iceland, which formed on a mid-ocean ridge.

\section{ACKNOWLEDGEMENTS}

I dedicate this work to the memory of the late Professor Ric Varne, of the School of Earth Sciences at the University of Tasmania, who stimulated my interest in Macquarie Island and who led a group of three to Macquarie Island in 1968. He recognised its global geological significance, reflected in its inscription on the World Heritage List in 1997 - an effort with which he was heavily involved. Varne Plateau on Macquarie Island has recently been named in his honour. 1 thank the organisers of the meeting held in 2006 to examine the sub-Antarctic, especially Sir Guy Green who was the originator of the idea. I am very grateful to Professors David Green and John Veevers whose reviews improved the final product. Many others have helped me in compiling this summary. I thank them all.

\section{REFERENCES}

Adamson, D.A., Selkirk, P.M., Price, D., Ward, N. \& Selkirk, J.M. 1996: Pleistocene uplift and palaeoenvironments of Macquarie Island: evidence from palaeobeaches and sedimentary deposits. Papers and Proceedings of the Royal Society of Tasmania 130: 25-32.

Banks, M.R. \& Smith, S.J. (eds) 1988: Macquarie Island. Papers and Proceedings of the Royal Society of Tasmania 122(1): 318 pp.

Barker, P.F.1990: South Sandwich Islands. In LeMasurier, W.E. \& Thomson, J.W. (eds): Volcanoes of the Antarctic Plate and Southern Ocean. Antarctic Research Series 48: 361-395.

Barling, J. 1994: Origin and evolution of a high-Ti ocean island basalt suite: the Laurens Peninsula Series, Heard Island, Indian Ocean. Mineralogical Magazine 58A: 49-50.

Bastien, T.W. \& Craddock, C. 1976: The geology of Peter I Island. Initial Reports, Deep Sea Drilling Project 35: 341-357.

Beggs, J.M., Challis, G.A. \& Cook, R.A. 1990: Basement geology of the Campbell Plateau: implications for correlation of the Campbell magnetic anomaly system. New Zealand Journal of Geology and Geophysics 33: 401-404.

Berggren, W.A., Kent, D. V., Swisher, C. C., III \& Aubry, M-P. 1995: A revised Cenozoic geochronology and chronostratigraphy. Society of Economic Paleontologists and Mineralogists Special Publication 54: 131-212.

Bonner, W.N. \& Lewis Smith, R.I. (eds) 1985: Conservation areas in the Antarctic. Scientific Committee on Antarctic Research, Cambridge: 299 pp.

Cande, S.C. \& Stock, J.M. 2004: Cenozoic reconstructions of the Australia-New Zealand-South Pacific sector of Antarctica. In Exon, N., Kennett, J.P. \& Malone, M. (eds): The Cenozoic Southern Ocean: tectonics, sedimentation, and climate change between Australia and Antarctica. American Geophysical Union, Geophysical Monograph 151: 5-17.

Chevallier, L. 1987: Tectonic and structural evolution of Gough Volcano: a volcanological model. Journal of Volcanological and Geothermal Research 33: 325-336.

Chevallier, L., Nougier, J. \& Catangrel, J.M. 1983: Volcanology of Possession Island, Crozet Archipelago (TAAF). In Oliver, R.L., James, P.R. \& Jago, J.B. (eds): Antarctic Earth Science. Australian Academy of Science, Canberra: 652-658.

Cookson, I.C. 1947: Plant microfossils from the lignites of Kerguelen Archipelago. Reports of the B.A.N.Z. Antarctic Research Expedition, series A, 2: 127-142.

Cunningham, A.P., Barker, P.F. \& Tomlinson, J.S. 1998: Tectonics and sedimentary environment of the North Scotia Ridge region revealed by side-scan sonar. Journal of the Geological Society of London 155: 941-956.

Cunningham, A.P. Larter, R.D., Barker, P.F., Gohl, K. \& Nitsche, F.O. 2002: Tectonic evolution of the Pacific margin of Antarctica 2. Structure of the Late Cretaceous-Early Tertiary plate boundaries in the Bellingshausen Sea from seismic reflection and gravity. Journal of Geophysical Research 107: (B12), EPM 6, doi: 10.1029/2002JB1001897.

Doucet, S., Weis, D., Scoates, J.S., Dehaille, V. \& Giret, A. 2004: Geochemical and $\mathrm{Hf}-\mathrm{Pb}-\mathrm{Sr}-\mathrm{Nd}$ isotopic constraints on the origin of the Amsterdam-St Paul (Indian Ocean) hot-spot basalts. Earth and Planetary Science Letters 218 : 179-195.

Duncan, R.A. 2002: A time frame for construction of the Kerguelen Plateau and Broken Ridge. Journal of Petrology 43: 1109-1119.

Embleton, B.J.J. 1984: Magnetic properties of oriented rock samples from Sturge Island and Sabrina Island in the Balleny group. In Lewis, D. (ed.): Voyage to the ice: the Antarctic expedition of Solo. Australian Broadcasting Commission, Sydney: 128-131.

Exon, N., Kennett, J.P. \& Malone, M. (eds) 2004: The Cenozoic Southern Ocean: tectonics, sedimentation and climate change between Australia and Antarctica. American Geophysical Union, Geophysical Monograph 151: 367 pp.

Fleming, C.A. 1957: A new species of fossil Chlamys from the Drygalski Agglomerate of Heard Island, Indian Ocean. Journal of the Geological Society of Australia 4: 13-19.

Fletcher, H.O. 1938: Marine Tertiary fossils and a description of a Recent Mytilus from Kerguelen Island. Reports of the B.A.N.Z. Antartic Research Expedition, series A, 2: $101-116$.

Francis, J.E. \& Coffin, M.F. 1992: Cretaceous fossil wood from the Raggatt Basin, southern Kerguelen Plateau (Site 750). Proceedings of the Ocean Drilling Program, Scientific Results 120: 273-280.

Frey, F.A., Coffin, M.F., Wallace, P.J. \& Weis, D. 2003: Leg 183 synthesis: Kerguelen Plateau-Broken Ridge - a Large Igneous Province. Proceedings of the Ocean Drilling Program, Scientific Results 183: 1-48.

Gamble, J.A. \& Adams, C.J. 1990a: Antipodes Islands. In LeMasurier, W.E. \& Thomson, J.W. (eds): Volcanoes of 
the Antarctic Plate and Southern Ocean. Antartic Research Series 48: 468-469.

Gamble, J.A. \& Adams, C.J. 1990b: Auckland Islands. In I.Masurier, W.E. \& Thomson, J.W. (eds): Volcanoes of the Antarctic Plate and Southern Ocean. Antarctic Research Series 48: $470-473$.

Gass, I.G., Harris, P.G. \& Holdgate, M.W. 1963: Pumice eruption in the area of the South Sandwich Islands. Geological Magazine 100: 321-330.

Giret, A. \& Lameyre, J. 1983: A study of Kerguelen plutonism: petrology, geochronology and geological implications. In Oliver, R.L., James, P.R. \& Jago, J.B. (eds): Antarctic Earth Science. Australian Academy of Science, Canberra: 646-651.

Green, T.H. 1992: Petrology and geology of basaltic rocks from the Balleny Islands, Antarctica. Australian Journal of Earth Sciences 39: 603-617.

Green, K. \& Woehler, E. (eds) 2006: Heard Island: Southern Ocean sentinel. Surrey Beatty \& Sons, Sydney: 270 pp.

Gregoire, M., Mattielli, N., Nicollet, C., Cottin, J.Y., Leyrit, H., Weis, D., Shimizu, N. \& Giret, A. 1994: Oceanic mafic granulite from the Kerguelen Archipelago. Nature 367: 360-363.

Gribnitz, K.H. \& Kent, L.E. 1989: Marine and fluviatile terraces and colluvial fans reflecting Quaternary climatic changes, Gough Island, South Atlantic. South African Journal of Antartic Research 19(1): 2-9.

Hansen, J., Sato, M., Kharecha, P., Russell, G., Lea, D.W. \& Siddall, M. 2007: Climate change and trace gases. Philosophical Transactions of the Royal Society A, 365: 1925 1954 (online at doi:10.1098/rsta.2007.2052).

Harris, C., Smith, H.S. \& Le Roex, A.P. 2000: Oxygen isotope composition of phenocrysts from Tristan du Cunha and Gough Island lavas: variation with fractional crystallization and evidence for assimilation. Contributions to Mineralogy and Petrology 138: 164-175.

Hart, S.R., Blusztajn, J. \& Craddock, C. 1995: Cenozoic volcanism in Antarctica: Jones Mountains and Peter I Island. Geochimica et Cosmochimica Acta 59: 33793388.

Headland, R. 1992: The Island of South Georgia. Cambridge University Press, Cambridge: 293 pp.

Hollis, C.J., Beu, A.G., Raine, J.I., Strong, C.P., Turnbull, I.M., Waghorn, D.B. \& Wilson, G.J. I997: Integrated biostratigraphy of Cretaceous-Paleogene strata on Campbell Island, southwest Pacific. Institute of Geological and Nuclear Sciences Report 97/25: $47 \mathrm{pp}$.

Ingle, S., Weis, D. \& Frey, F.A. 2002: Indian continental crust recovered from Elan Bank, Kerguelen Plateau (ODP Leg 183, Site 1137). Journal of Petrology 43: 1241-1257.

Jenkins, C.J., Packham, G.H., Hubble, T.C., Quilty, P.G. \& Adams, C.J. 1992: Trace of the Balleny hot-spot in the Tasman Sea and Southern Ocean from $70 \mathrm{Ma}$ to present. First Australian Marine Sciences Association meeting (Canberra) (abstract).

Johnson, K.T.M., Graham, D.W., Rubens, K.H., Nicolaysen, N., Scheirer, D.S., Forsyth, D.W., Baker, E.T. $8 x$ Douglas-Priebe, L.M. 2000: Boomerang Seamount: the active expression of the Amsterdam-St Paul hot-spot, Southeast Indian Ridge. Earth and Planetary Science Letters 183: 245-259.

Kyle, P.R. \& Cole, J.W. 1974: Structural control of volcanism in the McMurdo Volcanic Group, Antarctica. Bulletin Volcanologique 38: 16-25.

Lanyon, R. 1994: Mantle reservoirs and mafic magmatism associated with the break-up of Gondwana - the Balleny Plume and the Australian-Antarctic discordance. Unpublished PhD thesis, University of Tasmania.

Lanyon, R., Varne, R. \& Crawford, A.J. 1993: Tasmanian Tertiary basalts, the Balleny Plume and opening of the Tasman Sea (southwest Pacific Ocean). Geology 21: 555-558.
Larter, R.D., Cunningham, A.P., Barker, P.F., Gohl, K. \& Nitsche, F.O. 2002: Tectonic evolution of the Pacific margin of Antarctica 1. Late Cretaceous reconstructions. Journal of Geophysical Research 107: (B12), EPM5, doi: 10. 1029/2000\}B000052.

Leat, P.T., Larter, R.D. \& Millar, I.L. 2007: Silicic magmas of Protector Shoal, South Sandwich arc: indicators of generation of primitive continental crust in an island arc. Geological Magazine 144: 179-190.

Leat, P.T., Pearce, J.A., Barker, P.F., Millar, I.L., Barry, T.L. \& Larter, R.D. 2004: Magma genesis and mantle flow at a subducting slab edge: the South Sandwich arc-basin system. Earth and Planetary Science Letters 227: 17-35.

LeMasurier, W.E. \& Thomson, J.W. (eds) 1990: Volcanoes Of The Antarctic Plate and Southern Ocean. Antarctic Research Series, 48: $487 \mathrm{pp}$.

Maund, J.G., Rex, D.C., Le Roex, A.P. \& Reid, D.L. 1988: Volcanism on Gough Island: a revised stratigraphy. Geological Magazine 125: 175-181.

McDougall, I., Verwoerd, W. \& Chevallier, L. 2001: K-Ar geochronology of Marion Island, Southern Ocean. Geological Magazine 138: 1-17.

McGlone, M.S. 2002: Late Quaternary peat, vegetation and climate history of the southern oceanic islands of New Zealand. Quaternary Science Reviews 21: 683-707.

Mohr, B.A.R. \& Gee, C.T. 1992: An Early Albian palynoflora from the Kerguelen Plateau, southern Indian Ocean (Leg 120). Proceedings of the Ocean Drilling Program, Scientific Results 120: 255-271

Morris, P.A. \& Gamble, J.A. 1990: Campbell Island. In LeMasurier, W.E. \& Thomson, J.W. (eds): Volcanoes of the Antarctic Plate and Southern Ocean. Antarctic Research Series 48: 474-475.

Narcisi, B., Petit, J.R., Delmonte, B., Basile-Doelsch, I. \& Maggi, V. 2005: Characteristics and sources of tephra layers in the EPICA-Dome C ice record (East Antarctica): implications for past atmospheric circulation and ice core stratigraphic correlations. Earth and Planetary Science Letters 239: 253-265.

Nougier, J. 1982: Volcanism of Saint Paul and Amsterdam Islands (TAAF): some aspects of volcanism along plate margins. In Craddock, C. (ed.): Antarctic Geoscience. International Union of Geological Sciences, series B, 4: 755-765.

Nougier, J. \& Thomson, J.W. 1990a: Îles Crozet. In LeMasurier, W.E. \& Thomson, J.W. (eds): Volcanoes of the Antarctic Plate and Southern Ocean. Antarctic Research Series, 48: $42-428$.

Nougier, J. \& Thomson, J.W. 1990b: Îles Kerguelen. I $7 z$ LeMasurier, W.E. \& Thomson, J.W. (eds): Volcanoes of the Antarctic Plate and Southern Ocean. Antarctic Research Series, 48: 429-434.

Nougier, J. \& Thomson, J.W. 1990c: Amsterdam and Saint Paul Islands. In LeMasurier, W.E. \& Thomson, J.W. (eds): Volcanoes of the Antarctic Plate and Southern Ocean. Antarctic Research Series, 48: 442-445.

Patrick, M.R., Smellie, J.L., Harris, A.J.L., Wright, R., Dean, K., Izbekov, P., Garbell, H. \& Pilger, E. 2004: First recorded eruption of Mount Belinda volcano (Montagu Island), South Sandwich Islands. Bulletin of Volcanology Supplement 67: 415-422.

Peat, N. 2003: Subantarctic New Zealand: a rare heritage. Department of Conservation, Invercargill: $96 \mathrm{pp}$.

Prestvik, T., Barnes, C.G., Sundvoll, B. \& Duncan, R.A. 1990: Petrology of Peter I Øy (Peter I Island), West Antarctica. Journal of Volcanological and Geothermal Research 44: 315-338.

Quilty, P.G. 1995: Heard Island; offshore McDonald Islands. Bulletin of Volcanic Eruptions 32: 32-33, 127-128.

Quilty, P.G. 2006: Heard Island and the McDonald Islands: built on the Kerguelen Plateau foundation. In Green, K. and Woehler, E. (eds): Heard Island: Southern Ocean sentinel. 
Surrey Beatty \& Sons, Sydney: 1-9.

Quilty, P.G. Crundwell, M. \& Wise, S.W. Jr in press: 9 Ma age for sediments in the Macquarie Island ophiolite complex. Australian Journal of Earth Sciences.

Quilty, P.G., Murray-Wallace, C. \& Whitehead, J.M. 2004: Austrochlamys beardensis (Fleming, 1957) from Central Kerguelen Plateau, Indian Ocean: palaeontology and possible tectonic significance. Antarctic Science 16: 329-338.

Quilty, P.G., Shafik, S., McMinn, A., Brady, H., \& Clarke, I., 1983: Microfossil evidence for the age and environment of deposition of sediments of Heard and McDonald Islands. In Oliver, R.L., James, P.R. \& Jago, J.B. (eds): Antarctic Earth Science. Australian Academy of Science, Canberra: 636-639.

Quilty, P.G. \& Wheller, G. 2000: Heard Island and the McDonald Islands: a window into the Kerguelen Plateau. Papers and Proceedings of the Royal Society of Tasmania 133: 1-12.

Ritchie, D.D. \& Turnbull, I.M. 1985: Cenozoic sedimentary rocks at Carnley Harbour, Auckland Island, Campbell Plateau. New Zealand Journal of Geology and Geophysics 28: $23-41$

Rowley, P.D. 1990: Peter I Island. In LeMasurier, W.E. \& Thomson, J.W. (eds): Volcanoes of the Antarctic Plate and Southern Ocean. Antarctic Research Series, 48: 454-456.

Royer, J.-Y. \& Coffin, M.F. 1992: Jurassic to Eocene plate tectonic reconstructions in the Kerguelen Plateau region. Proceedings of the Ocean Drilling Program, Scientific Results 120: 917-928.

Royer, J.-Y. \& Sandwell, D.T. 1989: Evolution of the Indian Ocean since the Late Cretaceous: constraints from GEOSAT altimetry. Journal of Geophysical Research 94: 13755-13782.

Selkirk, P.M., Seppelt, R.D. \& Selkirk, D.R. 1990: Subantartic Macquarie Island Environment and Biology. Cambridge University Press Sudies in Polar Research, Cambridge: 285 pp.

Simpson, P. \& Griffiths, D.H. 1982: In Craddock, C. (ed.) Antarctic Geoscience. University of Wisconsin Press, Madison: 185-191.

Stephenson, J., Barling, J. Wheller, G. \& Clarke, I. 2006: The geology and volcanic geomorphology of Heard Island. In Green, K. \& Woehler, E. (eds.): Heard Island: Southern Ocean sentinel. Surrey Beatty and Sons, Sydney: 10-27.

Sutherland, F.L. \& Olsen, A.M. 1968: The persistence of drift pumice, from the 1962 South Sandwich Islands eruption, in southern Australasian waters. Papers and Proceedings of the Royal Society of Tasmania 102: 1-5.

Tanner, P.W.G. 1981: Turbidite sequences on South Georgia, South Atlantic: their structural relationship and provenance. In Thomson, M.R.A., Crame, J.A. \& Thomson, J.W. (eds): Geological evolution of Antarctica. Cambridge University Press, Cambridge: 353-359.

Thomson, M.R.A. \& Tanner, P.W.G. 1982: Fossil and radiometric evidence for ages of deposition and metamorphism of sedimentary sequences on Sourh Georgia. In Craddock, C (ed.): Antarctic Geoscience. University of Wisconsin Press, Madison: $177-184$.

Truswell, E.M., Quilty, P.G., McMinn, A. Macphail, M.K. \& Wheller, G. 2005: Late Miocene vegetation and palaeoenvironments of the Drygalski Formation, Heard Island, Indian Ocean: evidence from palynology. Antarctic Science 17: 427-442.

Varne, R., Brown, A.V. \& Falloon, T. 2000: Macquarie Island: its geology, srructural history, and the timing and rectonic setring of its N-MORB to E-MORB magmatism. Geological Society of America Special Publication 349: 301-320.

Varne, R., Gee, R.D. \& Quilty, P.G. 1969: Macquarie Island and the cause of oceanic linear magnetic anomalies. Science 166: 230-232.

Verwoerd, W.J. 1990a: Bouverøya. In LeMasurier, W.E. \& Thomson, J.W. (eds): Volcanoes of the Antarctic Plate and Southern Ocean. Antarctic Research Series 48: 405-410.

Verwoerd, W.J. 1990b: Marion Island and Prince Edward Island. In LeMasurier, W.E. \& Thomson, J.W. (eds): Volcanoes of the Antarctic Plate and Southern Ocean. Antarctic Research Series 48: 411-422.

Wertz K.L., Mosher, S., Daczko, N.R. \& Coffin, M.F. 2003: Macquarie Island's Finch-Langdon fault: a ridge-transform inside-corner structure. Geology 31: 661-664.

Wilson, T.J., Grunow, A.M., Hanson, R.E. \& Schmitt, K.R. 1991: Subduction-complex rocks on Diego Ramirez, Chile.In Thomson, M.R.A., Crame, J.A. \& Thomson, J.W. (eds): Geological Evolution Of Antarctica. Cambridge University Press, Cambridge: 419-421.

Wise, S.W Jr, Schlich, R., Palmer Julson, A.A., Aubry, M.-P., Berggren, W.A., Bitschene, P.R., Blackburn, N.A., Breza, J., Coffin, M.F., Harwood, D.M., Heider, F., Holmes, M.A., Howard, W.R., Inokuchi, H., Kelts, K., Lazarus, D.B., Mackensen, A., Maruyama, T., Munschy, M., Pratson, E., Quilty, P.G., Rack, F., Salters, V.J.M., Sevigny, J.H., Storey, M., Takemura, A., Watkins, D.K., Whitechurch, H. \& Zachos, J. 1992: Proceedings of the Ocean Drilling Program, Scientific Results. 120. College Station, TX (Ocean Drilling Program), 1155 pp.

Worthy, T.H. \& Jouventin, P. 1999: The fossil avifauna of Amsterdam Island, Indian Ocean. Smithsonian Contributions of Paleobiology 89: 39-65.

Wright, A.C. \& Kyle, P.R. 1990a: Balleny Islands. In LeMasurier, W.E. \& Thomson, J.W. (eds): Volcanoes of the Antarctic Plate and Southern Ocean. Antarctic Research Series, 48 : 449-451.

Wright, A.C. \& Kyle, P.R. 1990b: Scott Island. In LeMasurier, W.E. \& Thomson, J.W. (eds): Volcanoes Of The Antarctic Plate And Southern Ocean. Antarctic Research Series 48: 452-453.

(accepred 30 July 2007) 